\title{
Open game fences and their socio-spatial effects: Placing red deer, placing humans, managing territories
}

\author{
MARIE BALTZINGER!, ANDERS MÅRELL', \\ MARC DECONCHAT², RACHEL BARRIER' \\ ${ }^{1}$ Institut national de recherche en sciences et technologies \\ pour l'environnement et l'agriculture (IRSTEA) \\ 2 Institut national de la recherche agronomique (INRA)
}

\begin{abstract}
Big game populations have been rapidly increasing in temperate and boreal ecosystems worldwide, which has prompted the need to study the socio-ecological issues related to their management. In addition, the use of game-fencing has been spreading in certain rural areas, especially in French Sologne. These two parallel trends raise the issue of the new socio-spatial arrangements developing in rural areas. We set up an in-depth case-study combining stakeholder-interviews and ecological surveys (red deer trails, pellets and bed sites) to understand how game fences may affect both animal and human mobility, and why this may raise human conflicts. The study site was a $17.52 \mathrm{~km}^{2}$ fenced landscape comprising a public forest bordered on the north and south by two privately owned fenced lots. Both the interviews and the ecological data indicated that the fences were crossable for red deer. We did not find any fencing effect on the location of red deer trails, though red deer pellet groups were significantly more frequent outside fenced lots. On the other hand, we recorded more bed sites within fenced lots, in accordance with the stakeholders' statements that fenced lots had a high sheltering value for red deer. This implies that stakeholders have contrasting opportunities to encounter red deer because the fences deter non-owners from trespassing. Although any private owner has the legal right to fence his or her land under French law, our finding calls for more attention to how the fencing is designed, since its effects may impact the surrounding landscape. For instance, fences can allow a single owner to impose game management policies in the areas surrounding his or her estate.
\end{abstract}

KEYWORDS: Cervus elaphus; deer related conflict; human-deer relationships; private fencing; socio-ecological landscape 
Hence, by telling different 'stories' about the role of space and place as integral to human-animal relations, the essays below will provide much substance for reflection, particularly in the sense of suggesting the ethical charge that is carried by all situated human-animal encounters.

Philo \& Webert: Animal Spaces, Beastly Places (2000)

\section{Introduction}

Since the past century, rural areas in Europe have undergone critical socio-economic mutations and land use changes (van Vliet et al. 2015). By socio-economic mutation we mean a deep transformation of both social and economic systems, that co-occur and reinforce each other. Assessments of land-use trajectories have shown that forest expansion over previously cultivated areas is a common trend across Europe (Levers et al. 2015), and particularly in France (Mather et al. 1999). This forest transition together with hunting regulations, wild predator eradication, mean annual temperature increase and low winter mortality have triggered an increase in large ungulate populations all across Europe (Burbaite \& Csányi 2009; 2010; Massei et al. 2015). In France, hunting bags for red deer - Cervus elaphus - and wild boar - Sus scrofa - have increased 9.7-fold and 17.4-fold respectively in the past 40 years (ONCFS 2011). While providing ecosystem services such as wild meat (Schulp et al. 2014) and recreational services (García-Nieto et al. 2013), increasing ungulate populations can also conflict with the perpetuation of previous practices and land uses (Navarro \& Pereira, 2015). For instance, ungulates are known to deter forest regeneration through browsing (Pellerin et al. 2010). Viable populations of large herbivores do indeed require large areas of land, and at the same time, deeply affect plant communities (Wallis De Vries 1995; Rooney \& Waller 2003). More importantly, red deer impact on vegetation may be so widespread and important that it indirectly affects the whole ecosystem (Rooney \& Waller 2003; Bressette et al. 2012). That is why ungulate newcomers to many rural areas are currently shaping their own "beastly space" (Philo \& Wilbert 2000). Meanwhile, new conflicts are arising concerning land management and the placing of wild animals within post-rural landscapes (Heley and Jones 2012; Philo \& Wilbert 2000).

Hunting in Europe would appear to involve around 7 million people, which would directly contribute 16 billion euros to the economy of European rural areas (FACE 2010; 2016). The number of hunters appears relatively stable even though hunter recruitment 
is low (Massei et al. 2015). In France, 1.25 million people are recorded as hunters (BIPE 2015) and hunting could generate employment for 27,800 people in rural areas, and 3.9 billion euros in turnover (BIPE 2015). When we look beyond the mere numbers, we find that the hunters' social and geographical origins, hunting practices themselves and the relationships among hunters and with the other stakeholders have undergone significant changes in the last 50 years (Bromberger \& Lenclud 1982; Chamboredon 1982). The generalized increase in ungulate populations is among the drivers of these changes (Mounet 2012; Pelosse \& Vourc'h 1982). Game fences have become common tools for managing wild animals (Geisser et al. 2004); in France, they are now widespread in rural areas such the Brenne, the Landes and the Sologne (Baltzinger et al. 2016; Poinsot 2017).

Fencing can restrict access to certain areas for wild animals, domesticated animals and/or humans and may therefore be an efficient landscape management tool (Somers \& Hayward 2012). Like any other human-induced fragmenting feature, fences are likely to affect animal distribution in many ways (Fahrig 2003), especially for wideranging ungulates. Besides directly affecting animal movements, fencing may also modify habitat patch quality on either side of the fence, and by doing so, may affect how ungulates use and select their habitats. From a social landscape point of view (Field et al. 2003) fences can be viewed as land control tools (Peluso \& Lund 2011). They act as landmarks and allow the privatization of land and resources, territorialization and even the institutionalization of some particular access restrictions (Ribot \& Peluso 2003). Territorialization should not be understood as the mere exclusion of certain beings (human or animals) from a given area, but rather as the creation of ordered social relations, which are, in many cases, relations of dominance (Brighenti 2010). It is worth noting that most game fences are quite fragile structures that cannot be fully guaranteed against damage; indeed, they rarely act as impermeable barriers (Baltzinger 2016; Poinsot 2017). This is particularly true in the French Sologne, where a socio-ecological conflict arose in around 2010: the so-called "game fencing" (engrillagement ${ }^{1}$ ) problem.

The Sologne is a $5,000 \mathrm{~km}^{2}$ natural region in the center of France (Figs. 1 and 2). The area is characterized by its high forest cover, flat topography and poor clay/sand soils. Forests are typically rather open with low tree densities and high light availability. Deciduous trees represent approximately $77 \%$ of the forest cover (Quercus robur: $39 \%$, Quercus petraea: $14 \%$, Betula pendula: $9 \%$ ); among the conifers, Pinus sylvestris is the most frequent species (13\%). Red deer and wild boar populations have drastically

1 This word is a French neologism invented by local inhabitants to denote the spread of large fences all across the landscape. 
increased during the past 40 years throughout the region. In 2011, for example, hunting bags for red deer and wild boar in the Sologne region respectively averaged 1.2 and 8.0 individuals per $\mathrm{km}^{2}$ of forested area (ONCFS 2011). This means that red deer and wild boar populations in Sologne in 2011 were among the highest populations ever recorded in France since 1995 (Boulanger 2010). For several decades, the area seemed to have been undergoing a worrisome spread of private fences (Jacquet 2008; Legall 2012), which in 2011 led the public authority to launch a fence inventory program (Froissart 2011). The major concern at the time concerned the potential threat to ungulate populations, because the area is dedicated to leisure activities and is particularly dependent upon hunting from a socio-economic point of view. A survey of fences bordering roads in a $1,450-\mathrm{km}^{2}$ area, out of $5000 \mathrm{~km}^{2}$ for the whole Sologne region, showed that the area was criss-crossed by more than $670 \mathrm{~km}$ of fences (Fig. 2), of which more than $50 \%$ were in fact not sealed. This raised the question of the role played by such fences in the socio-ecological conflict, and led the regional authorities to fund an interdisciplinary research program on fences, red deer and the forest and its ecosystem services (http:// dysperse.irstea.fr/).

Figure 1: Map of France, with the Sologne region in grey.

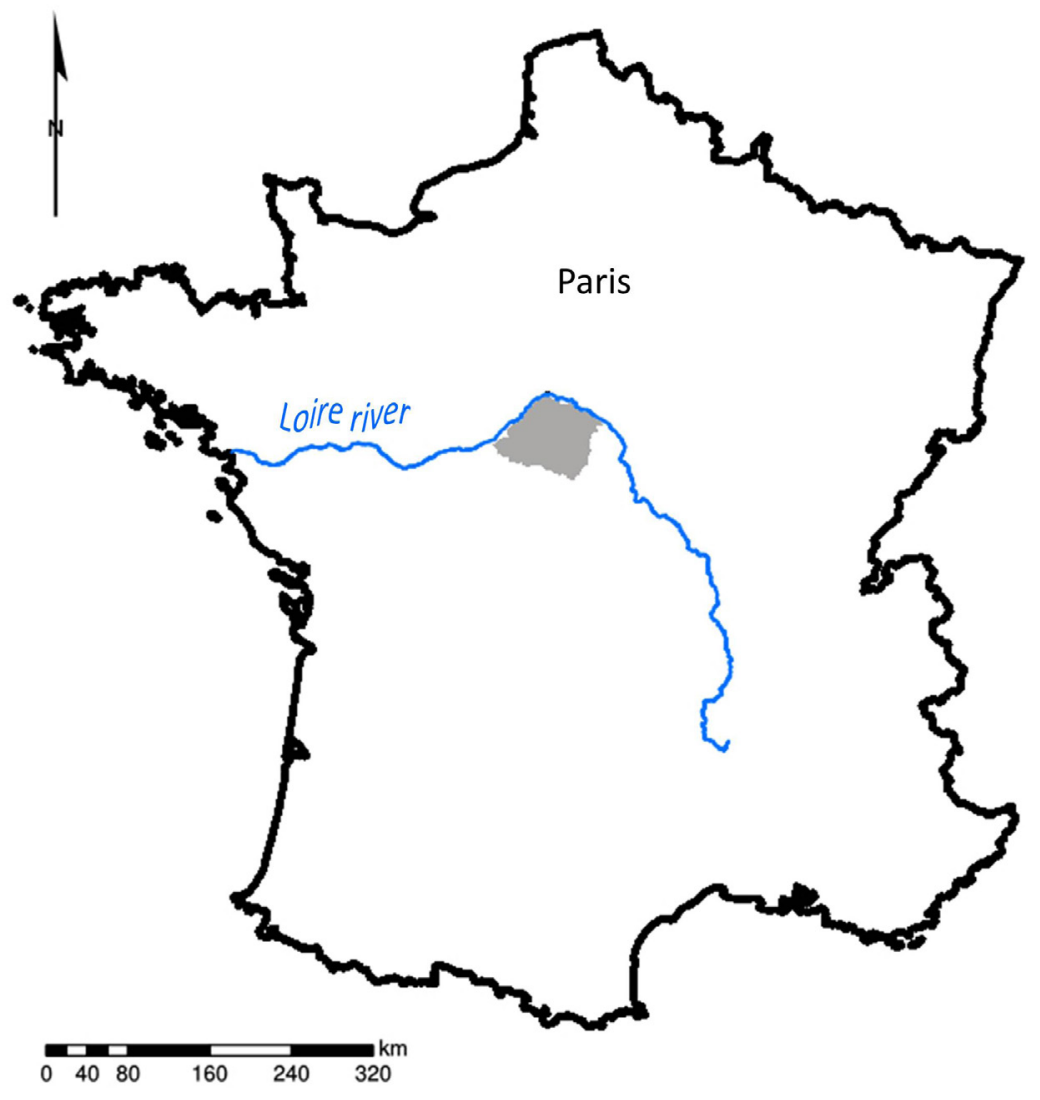




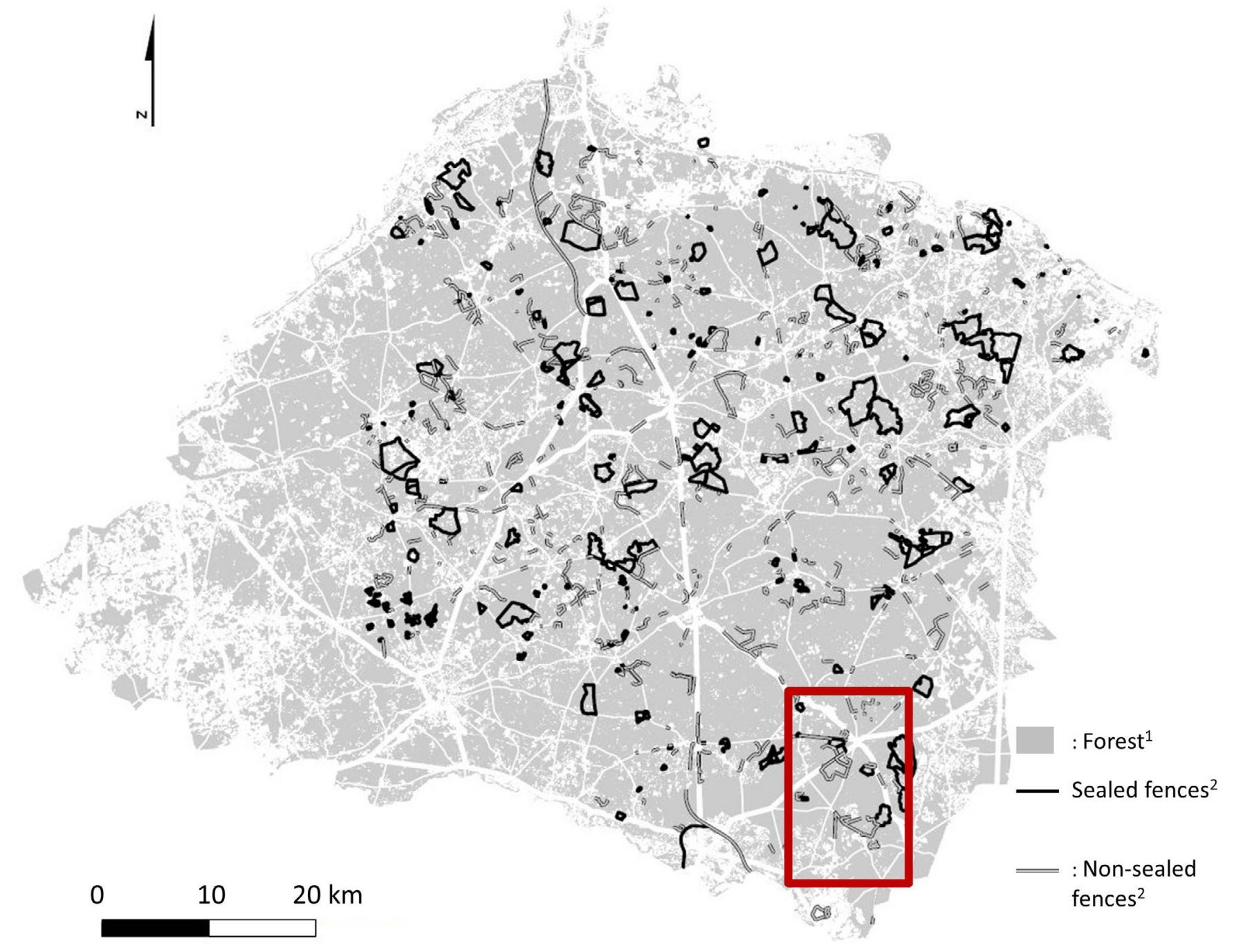

Figure 2: Map of the whole Sologne Region. The red square corresponds to the study site.

(1) Forest as defined by the French Forest Inventory (http://inventaire-forestier.ign.fr/spip/). (2) Fences.

In Sologne as in many other places, it is commonplace to state that humans are inescapably dependent upon animals - both for material resources (Lee \& DeVore 1966) and symbolic support (Lévi-Strauss 1962). Hunting - a particular kind of human-animal relationship - is considered a resource and has been a symbolically structuring practice for a long time (Hell 1998; Ingold 1987; Mendel 1977). Because hunting is by definition directed against wild animals, and because wild animals are supposed to run away on sight (Clutton-Brock 2002), the activity of chasing animals across wide areas is an integral component of this practice. Movement - of both men and animals - lies at the heart of the hunting activity, which implies that this specific human-animal relationship closely involves socio-spatial considerations (Ingold 1987). In this paper, we would like to emphasize the part played by animal spatiality in human sociality. By studying a given spatial feature - the game fence - associated with a specific animal-human relationship 
- hunting - we describe how socially constructed space is navigated by animals and humans. Because human and animal mobility underlies the achievability of human-animal encounters, we studied the effect of fences on hunting success. We ultimately investigated how contrasted hunting opportunities mirror social inequality among humans.

\section{Methods}

\subsection{A case-study embedded in a broader-scale research project}

Case studies have been used for many years across a variety of scientific disciplines because they allow us to understand how conflicts arise in real life, and how they are experienced by stakeholders. Case studies are deliberately limited in time and space, and they have been criticized for lacking generality (Flyvbjerg 2006). Still they prove very useful, especially when they are combined with broader attempts to grasp general trends at larger scales. Case study research can make use of different kinds of data from different scientific disciplines to build a comprehensive and in-depth depiction of complex issues (Flyvbjerg 2006). In this paper, we draw on the findings from a case study, which was set up in the framework of a broader research project. The following section describes the purpose of the whole research project, and the part played by the case study within the broader project.

It appears from the 1830 land register that, at that time, the Sologne region was owned by only a few rich land owners (Gillardot 1981); these private properties were for the most part dedicated to leisure activities, especially small game (birds and hares) hunting (Chardon 1993). The whole economy of the region was dependent upon the hunting activity, which provided employment and incomes (Chardon 1993; Gillardot 1981) in an otherwise barren and unfertile land (Young \& Betham-Edwards 2015). Hunting has remained one of the first economic activities in the area until today. From the beginning of the 20th century onwards, the area has been forest-covered (Gillardot 1981) and large ungulate populations have replaced birds and small mammals as target game. $90 \%$ of the forest area is privately owned at present. The emergence of high fences (more than $2 \mathrm{~m}$ ) across this natural region was observed in scientific studies as early as 1981 (Gillardot 1981), and later in 1993 (Chardon 1993). However, the speed with which fencing is spreading seems to have drastically increased during the past decade. In the early 2010s, a conflict developed in the local society concerning the 'engrillagement' problem which in many different ways reflected the bothersome effects these fences might have on red deer and wild boar populations (Devilleger et 
al. 2010; Jacquet 2008). The Dysperse interdisciplinary research program was launched in order to describe and analyze 'engrillagement' in Sologne. The project mixed both ecological methods intended to describe red deer spatial use and socio-ethnological inquiries to understand how fences were reshuffling the conceptual placing of red deer in the human ordering of the world (Philo \& Wilbert 2000). The ecological part of the research project revealed that fences did not critically deter red deer movement across the landscape (Masson 2015). This was in agreement with some opinions recorded by Mouche (2013), who was working on the socio-ethnological part of the project. However, newspaper content regularly mentioned the problem of game privatization, which, strictly speaking and from a legal point of view, should have led to sealing the fences. Game appropriation was also seen to be a problem, as expressed by stakeholders during interviews (Mouche 2013).

All these elements pointed to a seemingly paradoxical situation which led us to devise an in-depth case-study research program (Flyvbjerg 2006), mixing interviews and ecological surveys. As already mentioned, the Sologne has been privately owned for a long time, and is at present $90 \%$ privately owned. This makes the so-called "game privatization" problem related to fences even harder to understand. We therefore selected our study site in an area including a part of the remaining $10 \%$ of public land, in order to reflect how fences could be related to privatization.

In this study, we focused on a $17.52-\mathrm{km}^{2}$ fenced forested landscape representative of the Sologne landscape (Figs. 2 and 3). A public forest area lays in the middle of the study site, while it is bounded north and south by two privately owned fenced lots (in blue in Fig. 3) - hereafter we will refer to locations inside a fenced lot as "inside fence" and to the area between the two fenced lots as "outside fence". We set our study site boundaries to a scale consistent with a hind herd's home range in a temperate woodland forest (Patthey 2003); this scale is a fortiori consistent for a wild boar populations (Saïd et al. 2011). Forest cover (14.58 km² - 83\% of the area) dominates the $17.52-\mathrm{km}^{2}$ study area, but is interspersed with some small open areas (for a total of $2.94 \mathrm{~km}^{2}-17 \%$ of the area), defined as non-forested/non-urbanized areas (Fig. 3). Deciduous tree stands represent $36 \%$, conifers $51 \%$ and mixed stands $12 \%$ of the sampled area. Hunting bags (number of animals killed per $1 \mathrm{~km}^{2}$ of wooded area per year) from 2007 to 2011 varied between 2.7 and 4.0 for red deer and from 6.5 to 10.8 for wild boar. There is no animal predator within the area. Hunting is practiced according to three different, partially overlapping regimes: the public forest is leased twice, once for drive-hunting and once for hunting with hounds. The single private owner of the two fenced lots surrounding the area north and south has been licensed as a hound- 
Figure 3: Limits of the $17.52 \mathrm{~km}^{2}$ study area (white dotted line). Forest cover (grey) represents $14.58 \mathrm{~km}^{2}$. Sampled plots are displayed (red $=$ inside $/$ white $=$ outside fenced lots) together with the recorded red deer trails on each circular plot (70m radius).

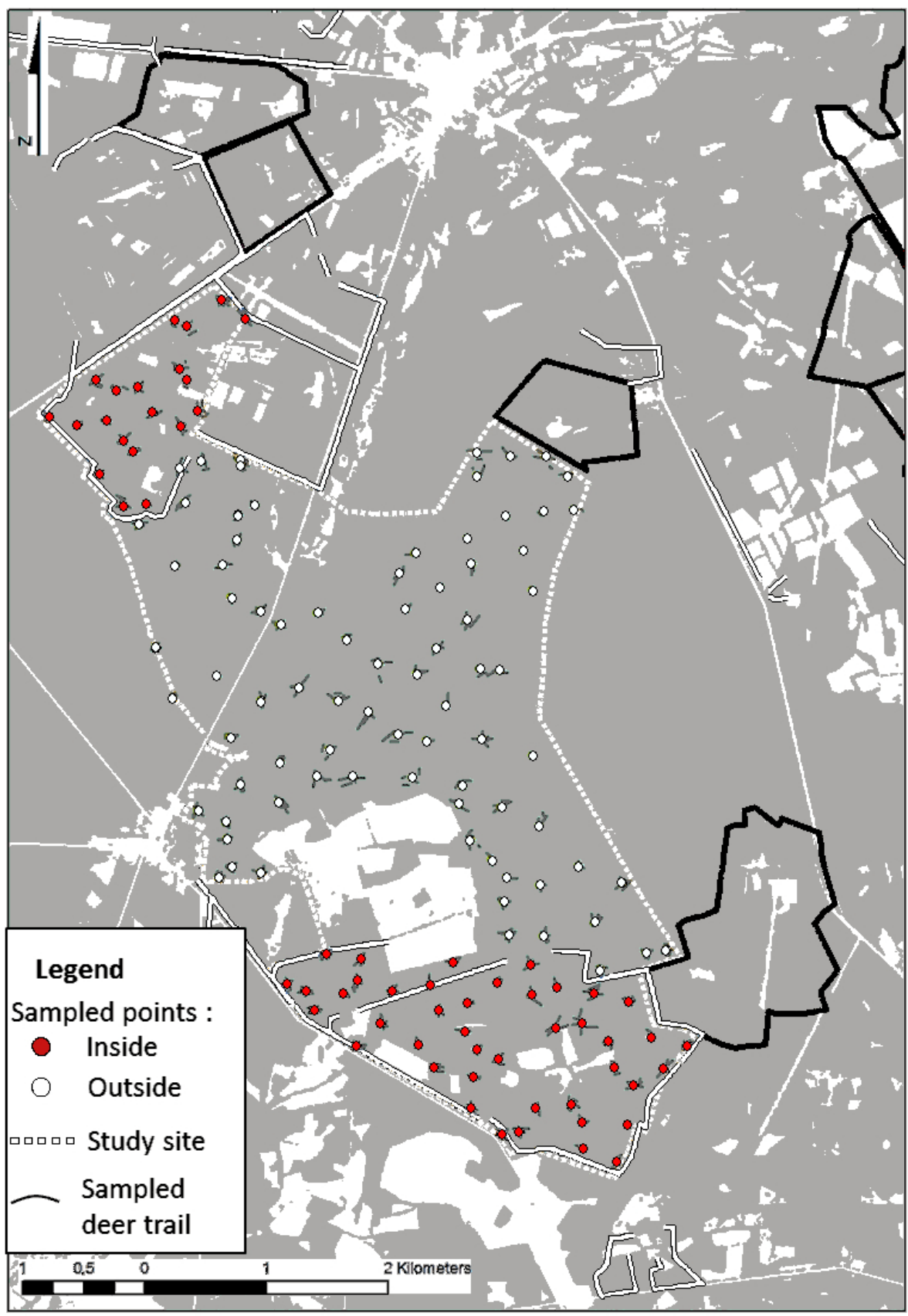

hunting Master for decades; he and his staff pursue red deer inside his lands as well as in the surrounding public forest. In addition, drive hunts are also practiced within the privately owned fenced lots. The national hunting authorities control hunting practices by setting yearly tag quotas. These quotas for red deer are quite high for the Sologne region and most of the years they exceed the actual number of bagged red deer. 


\subsection{Socio-ethnological data}

We conducted a total of six hours of semi-structured interviews with four stakeholders: two public forest managers, one public land game manager - also a member of the drive-hunt team, tenant within the public forest area - and the private owner of the two fenced lots - also hunt Master and tenant within the public forest area (see Fig. 5). We asked the four stakeholders to draw fences, human movement and red deer movement on a map (see Annex 2 and 3). Fieldwork (see below) was also an occasion of immersion in the area (4 weeks in total). The ecological protocol forced us to cross the area many times, which induced several casual meetings with the previously interviewed stakeholders. Interviews confirmed that the fences were believed to generate a problematic distribution of the local red deer population (see below). Together with the stakeholder mapping of human and red deer movements, these encounters allowed us to set the following two ecological investigation questions: how do the fences affect red deer movement patterns across the study area, and how do these fences affect the probability of human-red deer encounters (or, from an ecological point of view, what is the sheltering value of the fences for red deer - see below).

\subsection{Ecological data}

Fences may affect red deer's spatial use of an area either directly (barrier effect) or indirectly (habitat patch attractiveness). We studied red deer trail patterns throughout the study area to investigate the barrier effect of the fences. In addition, we recorded bed sites and pellet groups to test whether the fences affected habitat use, and if so, how. We hypothesized that all red deer trails, bed sites and pellets would be more concentrated behind one side of the fence if, indeed, the fencing design strongly constrained red deer movement within the area. On the other hand, even if the fencing design allowed red deer to move freely within the area, it might still affect habitat suitability and habitat patch attractiveness.

\subsection{Fences as barriers - red deer trail patterns}

In July 2013, we surveyed red deer trails at 145 circular (70m-radius), randomly located plots within the $14.58 \mathrm{~km}^{2}$ of forested area at the $17.52 \mathrm{~km}^{2}$ study site (Fig. 3). We chose a $70 \mathrm{~m}$ radius for our sampling plots because this scale is intermediate between the foraging and relocating scales for red deer (Anderson et al. 2008; Owen-Smith et 
al. 2010). Red deer space use is indeed known to be multi-scalar: home ranges usually consist of networks of discrete intensively used patches, or core areas (Fryxell et al. 2008). Therefore, indices of red deer presence are likely to occur in clusters within the landscape. We built a stratified random sampling design to select plots either inside or outside a fence (see Table 1). Because the study site also hosts quite a large wild boar population, we also wanted to determine whether the observed game trails were actually used by red deer, and not just by wild boar. We therefore adapted our sampling protocol to account for signs (especially hoof prints) that showed the game trails were being used by red deer. We drew inspiration from the adaptive line transect method used by Pollard and colleagues (2002) to design our sampling protocol. We set the sampling time at 15 minutes per plot, and allocated as much time as possible to following red deer trails. In practice (Fig. 4), we first randomly selected an azimuth and walked straight from the plot center in that direction until we either reached the $70 \mathrm{~m}$ edge of the plot or found a game trail. In the latter case, we deviated to follow the trail in any direction until we either reached the $70 \mathrm{~m}$ border of the plot or lost the trail. In either case, we then went back to the center of the plot and started another straight walk at the initial random azimuth +70 degrees. All walking time except for returns to the center of the plot were allocated to either Trail-following or Straight-walking events. For each trail, we GPS-located the point of encounter (i.e. where we crossed the trail) and the point where tracking stopped (plot edge or lost trail) so as to roughly estimate the length of the trail.
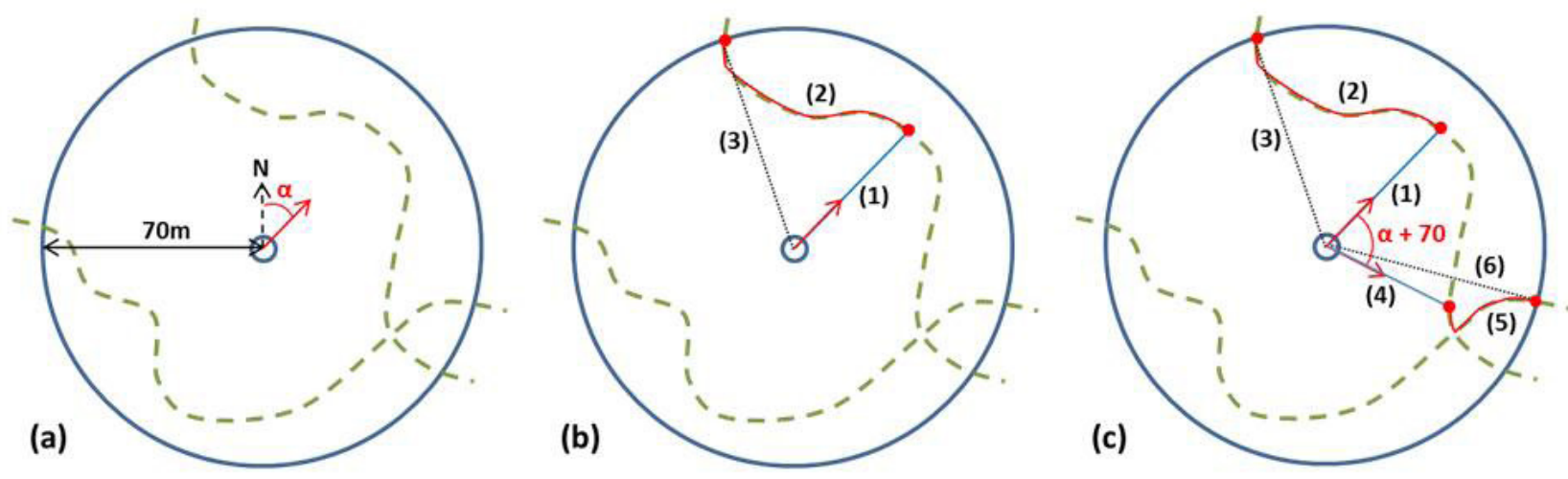

Figure 4: Sampling procedure (a) a 70m-radius circular plot crossed by a red deer trail (dashed line); (b) (1) straight-walking event in the randomly selected $\alpha$ azimuth (2) trail-following event (3) return back to the center (excluded from sampling time); (c) (4) straight walking event in a $\alpha+70^{\circ}$ azimuth (5) trailfollowing event (6) return back to the center (excluded from sampling time). The procedure was conducted for 15 minutes. For each trail-following and straight-walking event, the number of pellet groups and bed sites encountered was recorded. 
Figure 5: Schematic representation of the human mobility: the private owner (in red) is free to bunt across the study site, while the members of the drive-hunt team tenant within the public forest area (in blue) are not allowed to enter the fenced lots.

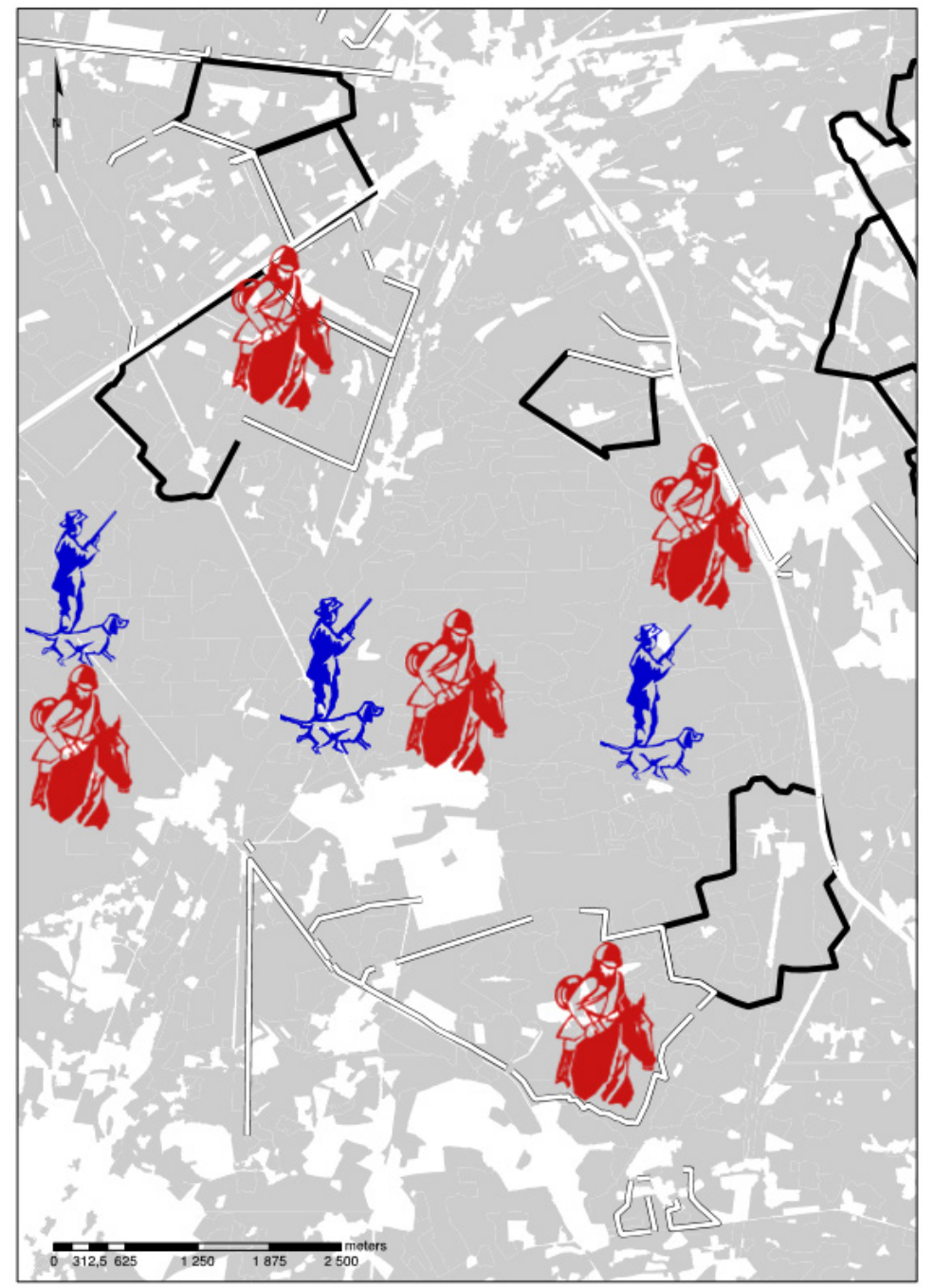

\subsection{Fence effect on habitat quality - sheltering value for red deer}

Habitat quality for wild animals is known to involve trade-offs: food availability plays a major role, together with other aspects such as predation avoidance (Mysterud \& Ims 1998; Brown 1999). Red deer, as a mixed-feeding ruminant (Hofmann 1989), is known to require both grazing and browsing areas for foraging, as well as safe resting places for ruminating (which represents nearly half of its time budget) (Mysterud 1998; Storms 2006). As the sampled plots were exclusively located in the forest (i.e. open areas were not sampled), their attractiveness as habitat could have been split into browsing quality (foraging) and resting (ruminating) site availability. However, the red deer densities encountered in this landscape (5-10 individuals $/ \mathrm{km}^{2}$ ) are so high that the forest understory is mostly depleted of palatable browse. We therefore hypothesized 
that only resting places would have an influence on habitat quality in the fenced areas. To assess the effect of fences on habitat quality (understood as sheltering value to avoid predation), we considered red deer pellets and red deer bed sites to be indicators of red deer use intensity. We recorded the number of pellet groups and bed sites encountered on the 145 sampling plots for all walking events except returns to the center, following the same sampling procedure described above (see Fig. 4). We expected pellet groups to be more abundant near bed sites, as defecations events are generally higher soon after leaving the resting place (Collins \& Urness 1981).

\subsection{Vegetation sampling - control variables}

For each plot, we visually estimated the mean height of the understory vegetation ( $<=2 \mathrm{~m}$ height) after the 15-min walking procedure was over. Ferns (Pteridium aquilinum, Dryopteris filix-mas, Dryopteris carthusiana, Athyrium filix-femina), grasses (Molinia caerulea, Deschampsia flexuosa, Juncus conglomeratus, Juncus effuses, Carex pilulifera) and heather (Calluna vulgaris, Erica cinerea) are often found to be competitively dominant understory species in forests, especially in our study site (Gaudio 2010). We therefore used these three cover types to classify understory vegetation composition. We used a ten-level discrete scale ( $10 \%$ regular intervals) to estimate the horizontal cover percentage for each cover type. We also recorded the type of forest stand (coppice, coppice with standards, high forest and open high forest; see Matthews 1991) and tree composition (pure deciduous, coniferous or a mixture of the two).

\subsection{Statistics}

We used ArcGIS software (ArcGIS Desktop 9.3.1) to measure the length of each walking event from the GPS-located starting and end points. Because walking events were nested within plots (i.e. several walking events for the same plot), we first combined the observations from all walking events during the 15-minute sampling period; we then calculated the cumulative trail length per plot and the number of recorded red deer trails per plot. Red deer are known to often re-use the same safe resting sites (Hamann et al. 1997), and hinds usually lie close to their related young (Clutton-Brock \& Guinness 1982). This implies that when one bed site is recorded, it is very likely to be close to several other bed sites. Therefore, to avoid confounding effects stemming from red deer site fidelity and group behavior, we summarized the bed-site recordings for each walking event with a binary variable which we set to 0 if no bed sites were 
observed during the walk, and to 1 if at least one bed site was observed. Secondly, because red deer pellets degrade quickly, we also used a binary variable to summarize the presence/absence of pellet groups during each walking event ( 0 when no pellets were found, and 1 when at least one pellet group was recorded). Thirdly, we used another binomial variable for the presence/absence of any red deer hoof prints found during the walk; we considered the number of prints to be uninformative and potentially misleading. Next, for each plot, we calculated the number of walking events with at least one bed site, the number of walking events with at least one pellet group, and the number of walking events with at least one red deer hoof print. Finally, we calculated the total number of walking events with any red deer presence indicator for each plot.

For each plot, we calculated Distance from plot center to nearest fence (ArcGIS Desktop 9.3.1). Because red deer are intermediate mixed feeders (Hofmann 1989), they are often found in woodland-edge habitats, and grazing in open areas accounts for about 30\% of their year-round diet (Gebert \& Verheyden-Tixier 2008). We therefore also calculated Distance from plot center to nearest open area. We hereafter refer to these two variables as "Landscape variables".

We first challenged the validity of our adaptive sampling method (Pollard et al. 2002) and investigated whether red deer pellet groups and red deer bed sites varied depending on whether we were on or off trails (trail-following versus straight walking). We fitted binomial mixed-effect generalized linear models to account for plot random effects (glmer function $R$ software, $R$ version 2.11.0).

We fitted linear models and generalized linear models ( $\mathrm{Im}, \mathrm{glm}$, anova functions) on vegetation and landscape variables to investigate if the fencing design could help predict where red deer move and where they rest in the landscape. Because any of the candidate co-variables may have interacted with the location of the plot, all twofold interactions involving the Inside/Outside Fence variable were tested. In addition, because the vegetation variables may have been redundant, we selected two sets of independent vegetation variables corresponding to two families of models: one "vegetation composition" family of models involving the non-redundant set of vegetation composition variables, and a "vegetation structure" family of models involving only mean understory vegetation height as a structural vegetation variable. Number of Recorded Trails and Number of Trails Associated with Bed Sites per plot were fitted as being Poisson distributed (generalized linear models) whereas Trail Length per plot was fitted as being normally distributed (Im function). For each red deer-related variable, and for each model family (either "composition" or "structural"), we used the dredge function (Barton 2013) to perform an automated AICc-based model selection on each 
model nested in the full model at hand. Among the models whose AICc was within two points of the best model, we selected the one with the least number of variables (Burnham and Anderson 1992). We ultimately used Anovas (normally fitted $F$ test with a linear regression for track length; Poisson-fitted Chi square tests with generalized linear models for number of red deer tracks, number of red deer pellet groups and number of red deer bed sites) to test our models against the following null hypothesis: "the studied red deer-related variable is evenly distributed throughout the observed landscape".

\section{Results}

\subsection{Socio-ethnological data}

Local stakeholders agreed that the $17.52 \mathrm{~km}^{2}$ study site (Fig. 3) was the home range for a red deer herd of about one hundred individuals ( 5 to 10 individuals $/ \mathrm{km}^{2}$ ), made up mostly of females and young, except during the rutting season when males and females congregated around a highly attractive mating site at the center of the area. Wild boar are locally numerous in the northern part of the area but did not appear to be of concern for any of the interviewed stakeholders. Indeed, all the interviewees focused their interest on the red deer population. However, they strongly disagreed in their representations of the fences. Original quotations in French are provided in Annex 1.

In line with Mouche's (2013) findings, all four stakeholders in the study site agreed that the spread of fencing was triggered by the boom in both red deer and wild boar populations and the aversion to human trespass in private forests.

Eh, well, I don't hardly know any owners who fence their place to keep the animals from coming in! It's mostly to keep them from getting out! [...] And then it also... it, eh, prevents the animals from getting out and it also, eh, discourages... eh, even if you need at least one meter, eh, it also discourages people from coming in! (Hunter from the study site) (1)

All stakeholders considered that most red deer used the whole study site every day therefore crossing the fences many times a day.

So after, there's... there's movement, you know [...]. Actually, game trails, if you look at the game trails. [...] Well, you know there is a tremendous number of game trails! You'll have game trails everywhere, you know. [...] they're coming and going like they want, you know, so we can say all along it, you know. (Hunter NOT allowed to hunt inside fenced lots) (2) 
This is important, because in French law, wild animals such as red deer are considered "res nullius" (owned by no one) unless they are enclosed in a perfectly sealed fence in that case, they become "res propria" (the property of the fence owner). If red deer can cross the fence, then they remain "res nullius". All four stakeholders knew of this law, and mentioned it regularly during the interviews. The only way to appropriate red deer in this case is to kill them, by hunting. However, hunting is codified by law and by custom. By law, hunting is regulated by tag quotas, but these yearly quotas are rarely, if ever, reached. In practice, the hunting rate is lower than the quota. Most of the time, the limiting factor is hunting success. By custom, hunting should be "fair" (Baltzinger et al. 2016), but fairness is not well defined and depends on each hunter's attitude. Having said this, we can understand the notion of "trap blame" as being included in the broader context of "privatization blame": fences are in fact blamed as non-ethical. Therefore, they are believed to cause an unfair appropriation of the red deer.

Why a trap? Well, because when you have [...] I mean, if you have a place you want to choose to be able to take some animals... If I... I'm sorry but it's a kind of a trap! [...] If somebody asks me to hunt those animals, hmm, I know right where I'm gonna go, I mean to take them out! (Hunter NOT allowed to hunt inside fenced lots) (3)

This idea that "U-shaped-fencing" or "three-faceted-fencing" acts as a trap was widespread among stakeholders in the whole Sologne area, and even among other hunters interviewed from neighboring areas (Mouche 2013). The interviewees do not mean that the fences kill the red deer directly, but rather that they improve success for the hunters allowed to enter the fenced area.

In addition, all the stakeholders considered that the red deer spent most of their time browsing, resting or ruminating inside the fenced lots during the day, while they usually browsed outside the fenced lots at night.

OK, so do you usually sleep in your dining room? No, you sleep in your bedroom. So, OK, the animals, they come and eat, and in the evening, they... at night, they come and eat, and in the morning, they go back to my place to sleep. (Private owner of the fenced lot) (4)

This statement that the fences are permeable for red deer was consensual among all four stakeholders. For foresters, this was considered problematic because fence permeability allowed red deer browsing pressure to spread to the public forest from overpopulated private holdings. 
Yes but the... the damage, you have that even so because the animals come over at night. [...] So, it's a fact, hmm, l'd say, yeah, actually the animals aren't on our land any more, yeah! [...] but they're still in the area, the larger area. OK. So they come back to eat [...]. They go back and forth, hmm, it's a nocturnal migration, hmm, over long distances, you see! (Forester) (5)

The hunter with no access to the fenced lot blamed the fencing for making red deer hunting difficult in the public area, whereas the private owner (also a hunter) expressed his full satisfaction.

The place where the most deer are killed in the region is right here! [...] OK, just quickly: there won't be any animals left anywhere and they'll all be here on this property. [...] So, our bet is that the global population is decreasing and since the global population has gone down, we'll still always have enough to hunt. (Private owner of the fenced lot) (6)

We hmm... to try to set up a hunting area at one time, we got up at four in the morning to try to put up flagging tape to try to keep them out of the park! And we... hmm... I'm not talking about just a couple of animals, you know! It was... like... we put up flagging tape along $1.5 \mathrm{~km}$ because we had to go wide, you know. (Hunter NOT allowed to hunt inside fenced lots) (7)

Ultimately, it appeared that the stakeholders disagreed about the desired red deer population density for the area as a whole. This appeared to be problematic insofar as the private owner was considered to have much more latitude to impose his own desired red deer population density.

Two for a hundred ha, that's nonsense, it's nonsense. If you want my opinion, a balanced population is between three and four deer to a hundred ha, that's it. Yeah, that's what you need. That's my opinion, it's the minimum. Five, that's too much; don't go over five. OK, five, five is, I mean, you have to start taking action at five, but three or four animals is ideal. (Private owner) (8)

If we were at, I'd say, two animals to a hundred ha... hmm... that wouldn't be any problem for us at all. [...] There's an internal memo... hmm... in the Agency from 1994... hmm... in our area, they recommend 1.5 to two deer per hundred ha. (Forester) (9) 


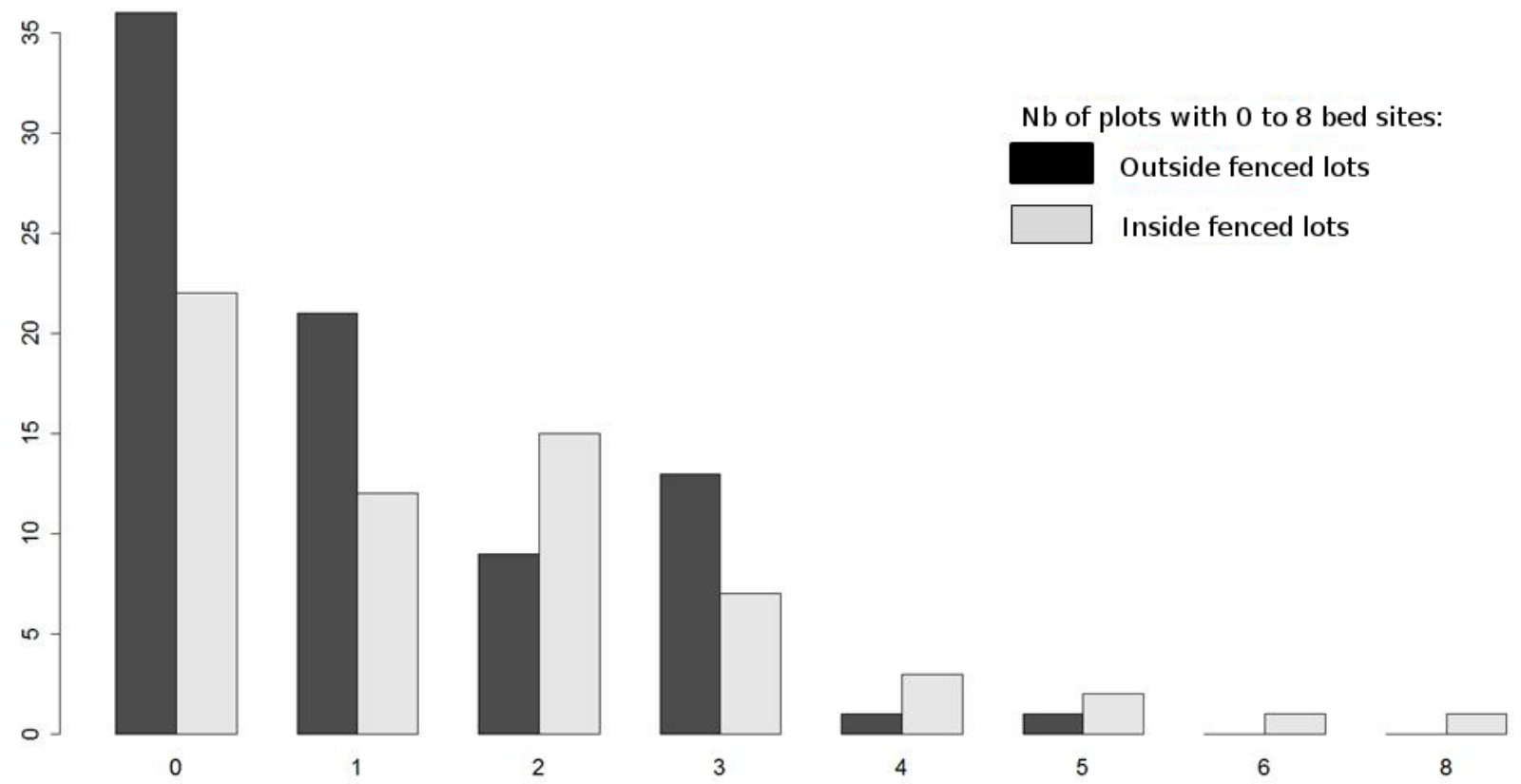

Figure 6: Number of plots with $n$ bed sites outside (black) and inside (grey) fenced lots, $n$ ranging from 0 to 8.

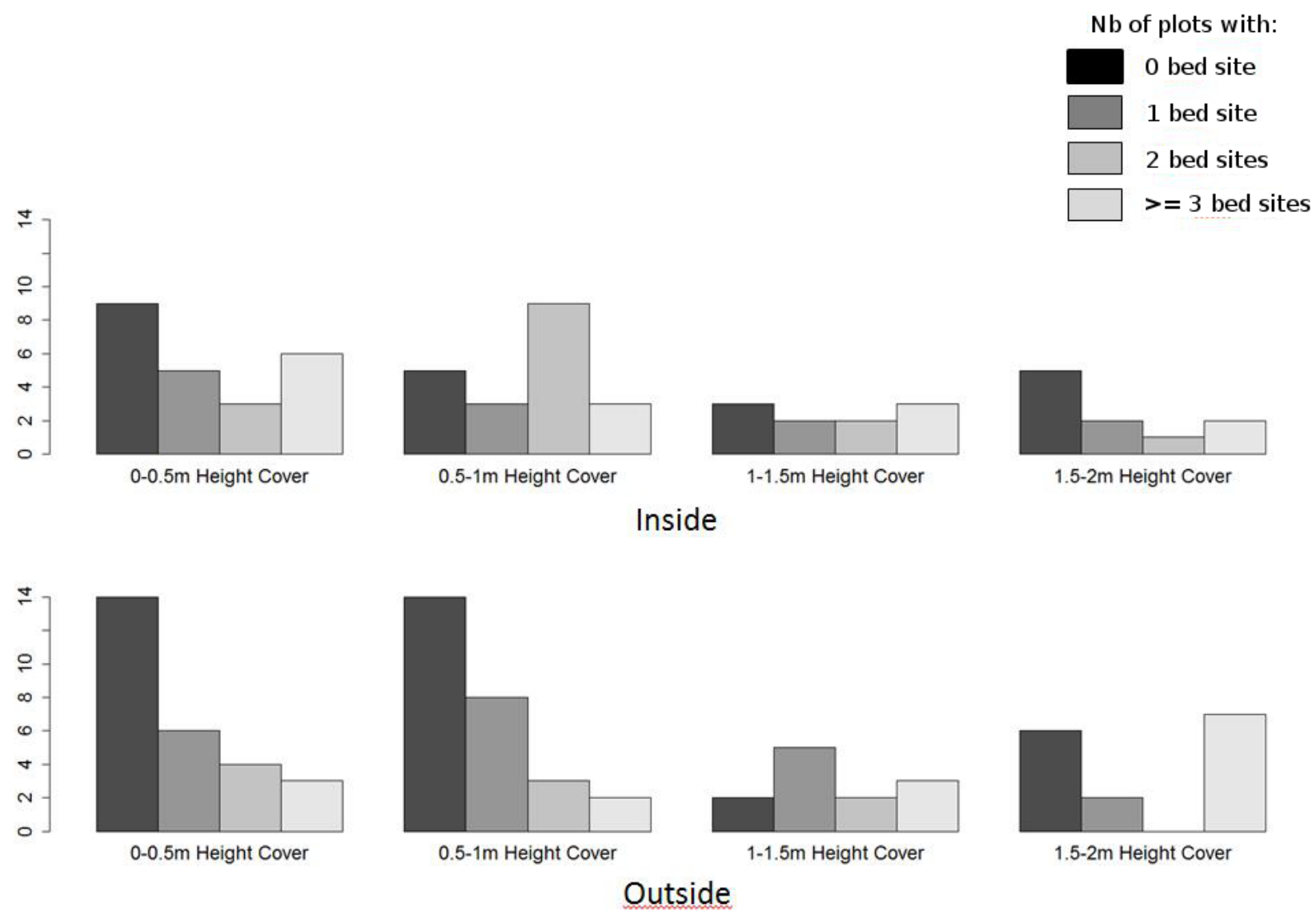

Figure 7: Histograms of plots with $n$ bed sites at 4 mean understory vegetation heights Inside (top) and Outside (bottom) fenced lots, $n$ ranging from $O$ to $>=3$. 


\subsection{Ecological data}

Overall, 1,636 walking segments were recorded among which 611 were trail-following events - equivalent to $929 \mathrm{~min}$., $37 \mathrm{sec}$. (Table 2). We recorded 319 bed sites during 186 walking events: 85 straight walking events ( 138 bed sites recorded) and 101 trail-following events (181 bed sites recorded). Pellet groups were found during 132 walking events: 43 were straight walking events and 89 trail-following events. Binomial mixed-effect generalized linear models (accounting for plot random effect) significantly associated both recorded bed sites and recorded pellet groups with trail-following events (Bed sites: $\chi 21=27.6$, p.value < 0.001; Pellet groups: $\chi 21=54.3$, p.value $<0.001$ ). At least one red deer trail was found on 138 plots out of the total 145 plots sampled. On 132 of these 138 plots, at least one other sign of red deer presence was found (either hoof print, bed site or pellet group). All trail-related variables were highly correlated, especially trail length and trail-following duration (Pearson correlation coefficients: length/duration $=0.93$, length $/ \mathrm{nb}=0.85$ ).

\subsection{Vegetation variables}

Both canopy tree-type composition and stand management proved to be redundant with understory cover variables. Grass cover percentage was systematically lower under conifers and higher under deciduous canopies; intermediate values were found for mixed stands (Anova: Sum.Squares = 1.97, p.value < 0.001, Adjusted R-squared: 0.12). Mean vegetation height was significantly lower under coppice with standards than under open high-forest stands. Values under coppice and high stands were between these two extremes (Anova: Sum.Squares $=3.836$, p.value $=0.002$, Adjusted R-squared: 0.08). We therefore considered understory cover variables - i.e. grass cover, fern cover and heather cover - to be a representative non-redundant set of vegetation composition variables and included them in the "vegetation composition" model family.

Among vegetation composition variables, we considered mean understory vegetation height to be a good surrogate for vegetation structure and included it as the only vegetation variable in the "vegetation structure" model family.

\subsection{Red deer trails}

Among all models from both the "vegetation composition" and the "vegetation structure" families, red deer trail length was best fitted by a model involving Distance to nearest open area and grass cover (negative effect) (Im: Sum.Squares $=270909, \mathrm{df}=2$, 
p.value $<0.001)$. No fence-related variable ever significantly improved the models' fit (see Table 3 and Fig 3). Even when vegetation effects were accounted for as finely as possible (as in the "vegetation composition" model family), fencing effect still remained unable to predict the location of red deer trails.

\subsection{Red deer pellet groups}

Red deer pellet groups were significantly more frequent outside fenced lots (see Table 3). The best model belonged to the "vegetation composition" model family with grass cover as a predictive variable (negative effect), together with Fencing and Distance to nearest open area (glm: $\chi 23=31.1$, p.value $<0.001$ ).

\subsection{Red deer bed sites}

Bed sites were significantly more frequent inside fenced lots. As opposed to the previously mentioned patterns, the best model for bed sites belonged to the "vegetation structure" family with mean height of understory vegetation alone providing a lower AICc than any "vegetation composition" family models ( $\triangle \mathrm{AICc}>4-$ see Table 3 ). This best model for bed sites retained the Fencing as the main factor with two different interactions: fencing with mean height of understory vegetation and fencing with Distance to nearest open area ( $\mathrm{glm}: \chi 26=32.8$, p.value $<0.001$ ). Mean understory vegetation height, Distance to the nearest fence and Distance to the nearest open area were also components of the best model.

Surprisingly, we observed a decrease in the probability of recording pellet groups (see paragraph above) concomitant with an increase in the probability of recording bed sites inside fenced areas. In fact, no correlation proved to be significant between these two red deer presence signs ( $\mathrm{glm}: \chi 29=8.274$, p.value $=0.5068$ ).

Another interesting result revealed by this model was that a positive effect of vegetation cover - as expressed by mean vegetation height - on bed-site abundance was observed only outside fenced areas (Fig. 6, 7).

\section{Discussion}

From both stakeholders' interviews and recorded ecological data, it appears that red deer segregate their activity according to the fencing design, even though they easily and frequently cross the fences. In particular, bed sites proved to be more frequent 
inside fenced lots, in agreement with the views of the interviewed stakeholders from the study site. No fence-related variables significantly explained red deer trail patterns in any model family, which is also consistent with stakeholders' claims that red deer roam freely throughout the whole study area. These findings are also consistent with Masson (2015) who showed that fences do not deter red deer circulation at the regional scale for all of Sologne. However, the interviewed stakeholders from the study site regularly blamed the fences for conflicting with the "res nullius" status of wild game, which is in line with other opinions recorded at the region-wide scale (Mouche 2013). The question remains as to how this stated conflict articulates with the statement that red deer easily cross the fences. Interestingly, the interviewed stakeholders from the study site consistently considered the fenced lots as safe resting places for red deer.

Bed sites were significantly more frequent inside fenced lots. Furthermore, bed site selection patterns varied depending on the location inside/outside a fenced lot. Outside fenced lots, bed sites were more numerous in locations with high understory vegetation and near open areas; but both of these effects tended to fade out inside the fenced areas. Red deer are known to select locations with high vegetation cover as resting sites (Baltzinger 2003), but they also need to forage, especially in open areas (Storms 2006). However, the sheltering value of being inside a fenced lot may be high enough that neither vegetation cover nor open area proximity affects bed site selection there. When exposed to predation risk or human disturbance, wild animals are known to modify their habitat preference and to avoid the most exposed patches (Brown 1999; Jayakody et al. 2008), even when this incurs costs in terms of food intake. This is particularly true during calving season for female red deer with young (CluttonBrock \& Guinness 1982). Accordingly, most of the interviewees at the Sologne scale considered that wild animals would flee on sight as a very definition of "wildness" (Mouche 2013). This is momentous in Sologne because the critical difference between hunting and cattle breeding is that game animals must be considered wild, at least from a symbolic point of view (Baltzinger et al. 2016; Hell 1998). Private fencing basically eliminates human trespassers, thus enhancing the sheltering value of these areas for red deer. Meanwhile, fences contribute to keeping red deer "wild" because the animals remain less used to humans (Baltzinger et al. 2016). All the stakeholders from the Sologne region split the hunter population into two groups: "true" hunters and those who in fact kill "tame" animals (Baltzinger et al. 2016).

Though some female red deer modify their home ranges depending on the season (Clutton-Brock \& Guinness 1982), all the interviewed stakeholders from the study site agreed that this was not the case in the study area. Site fidelity is a strong 
component of female red deer habitat use, especially in spring and summer (CluttonBrock \& Guinness 1982). In particular, Webb and colleagues (2010) observed strong hind fidelity to fenced enclosures - hinds spent most of their time within fenced areas even when the fences were crossable. Moreover, several authors state that risk avoidance rather than foraging for food shapes red deer home ranges under certain ecological conditions (Hamann et al. 1997). At our study site, the stakeholders agreed that red deer spent most of their time inside the fenced lots all year round. Interestingly, this remains true even if some hunting events take place occasionally within the fenced lots (see quotation 6 above). This is in agreement with Hamann and colleagues' (1997) findings that few hunting events drastically modify red deer space use, except on the day of the hunt. As outlined in the quotations above, there is a critical difference in hunting success depending on the location of the hunt relative to the fences: hunters in the public area incur the risk that the red deer they are chasing will flee towards fenced lots, where the hunters would not be licensed to pursue them (quotations 3 and 7). Inversely, the private owner benefits from very high hunting success (quotation 6 ). This strong inequality in hunting success in turn implies that the private owner can impose his own hunting policy with regard to the deer population density for the entire area (quotations 8 and 9).

To summarize, it appears that the fences in our study area do not deter red deer movement, while they do contribute to regulating human movement and activities (compare Fig. 5 and 8). While the private owner is licensed to hunt throughout the area, the non-owners rely on his agreement to pursue red deer once they have entered his land. Meanwhile, the private owner is able to fix the desirable red deer abundance over the whole area, notwithstanding what the public forest managers would condone. However, large red deer populations are known to jeopardize forest regeneration and forest cover in the long run (Hothorn \& Müller 2010; Martin \& Baltzinger 2002). This is precisely what the public forest manager had in mind when she exclaimed "But you know, it is not possible to protest, because... well, you know it's the empire eh!" (see also quotation 5). In conclusion, we would like to suggest that the disagreement here does not merely concern privatization but also territorialization (Peluso \& Lund 2011). As stated by Brighenti (2010): "Territory is not defined by space, rather it defines spaces through patterns of relations". We interpret this struggle over fencing as two competing strategies to institute certain kinds of relations between red deer and different groups of humans in our study area. 
Figure 8: Schematic representation of the red deer mobility: red deer are free to travel across the study site (dotted lines) but they spend most time inside fenced lots for resting and ruminating at day time.

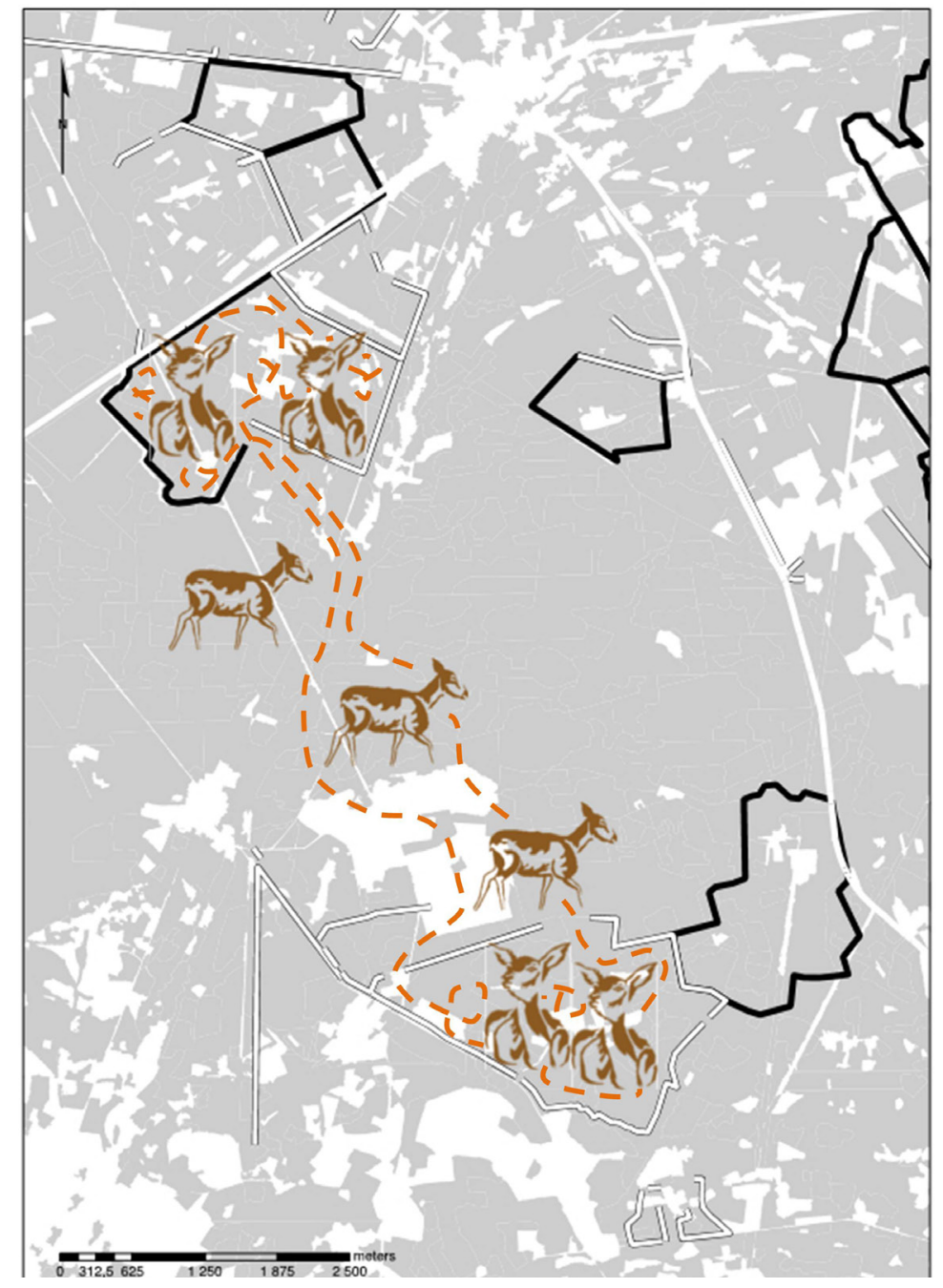

\section{Conclusion}

In the past 40 years, socio-ecological mutations in rural areas have triggered an increase in big game populations in many temperate landscapes, especially in France (Poinsot \& Saldaqui 2009; ONCFS 2011; Chollet 2012). These drastic big game population booms have corresponded to a drop in small game populations, and more importantly, to the abandonment of agriculture in many rural areas. These trends were both causes and consequences of dramatically reshaped social relationships in the French countryside among farmers, foresters and hunters (Pelosse \& Vourc'h 1982; Poinsot \& Saldaqui 2009; Mounet 2012). In particular, Poinsot \& Saldaqui (2009) argue for a complete rethinking of spatial management for hunting practices, together with a reorganization of hunting societies. The Sologne case is interesting in that the region was never previously farmed: here, there was a shift in the type of species hunted, from small game to 
big game. However, the increase in wide-ranging big game animals in Sologne encountered a tradition of private ownership and individualistic hunting practices which had been efficient as long as small-game hunting was the main focus. This confrontation partly explains the spread of private fencing in the area: the intent was to keep on hunting the same way, even though the game species had changed (Baltzinger et al. 2016). However these individualistic practices do not seem to provide a relevant basis for the sustainable management of ever-increasing big game populations. The fencing dispute illustrates how new hunting practices, hunting ethics and socio-spatial arrangements are needed in order to build a new socio-ecosystem which would be consensual and ecologically consistent. 
Table 1: Summary of the sampled plots and recorded red deer presence indicators

\begin{tabular}{|c|c|c|c|c|c|c|}
\hline \multicolumn{2}{|c|}{ Location } & $\mathrm{Nb}$ of plots & $\begin{array}{c}\text { Nb of re- } \\
\text { corded trails }\end{array}$ & $\begin{array}{c}\text { Nb of pellet } \\
\text { groups }\end{array}$ & $\begin{array}{c}\text { Nb of } \\
\text { recorded } \\
\text { bed sites }\end{array}$ & $\begin{array}{l}\text { Nb of } \\
\text { groups of } \\
\text { bed sites }\end{array}$ \\
\hline \multicolumn{2}{|c|}{ Outside Fenced Area } & 82 & 313 & 95 & 135 & 88 \\
\hline \multirow{3}{*}{$\begin{array}{c}\text { Inside } \\
\text { fenced Area }\end{array}$} & North & 20 & 89 & 14 & 49 & 30 \\
\hline & South & 43 & 209 & 23 & 135 & 69 \\
\hline & Total Inside & 63 & 298 & 37 & 184 & 99 \\
\hline \multicolumn{2}{|l|}{ Overall Total } & 145 & 611 & 132 & 319 & 187 \\
\hline
\end{tabular}

Table 2: Summary of the recorded ecological variables: mean and standard deviation are given for quantitative variables; $\dagger$ for qualitative variables (factor), the number of plots is given.

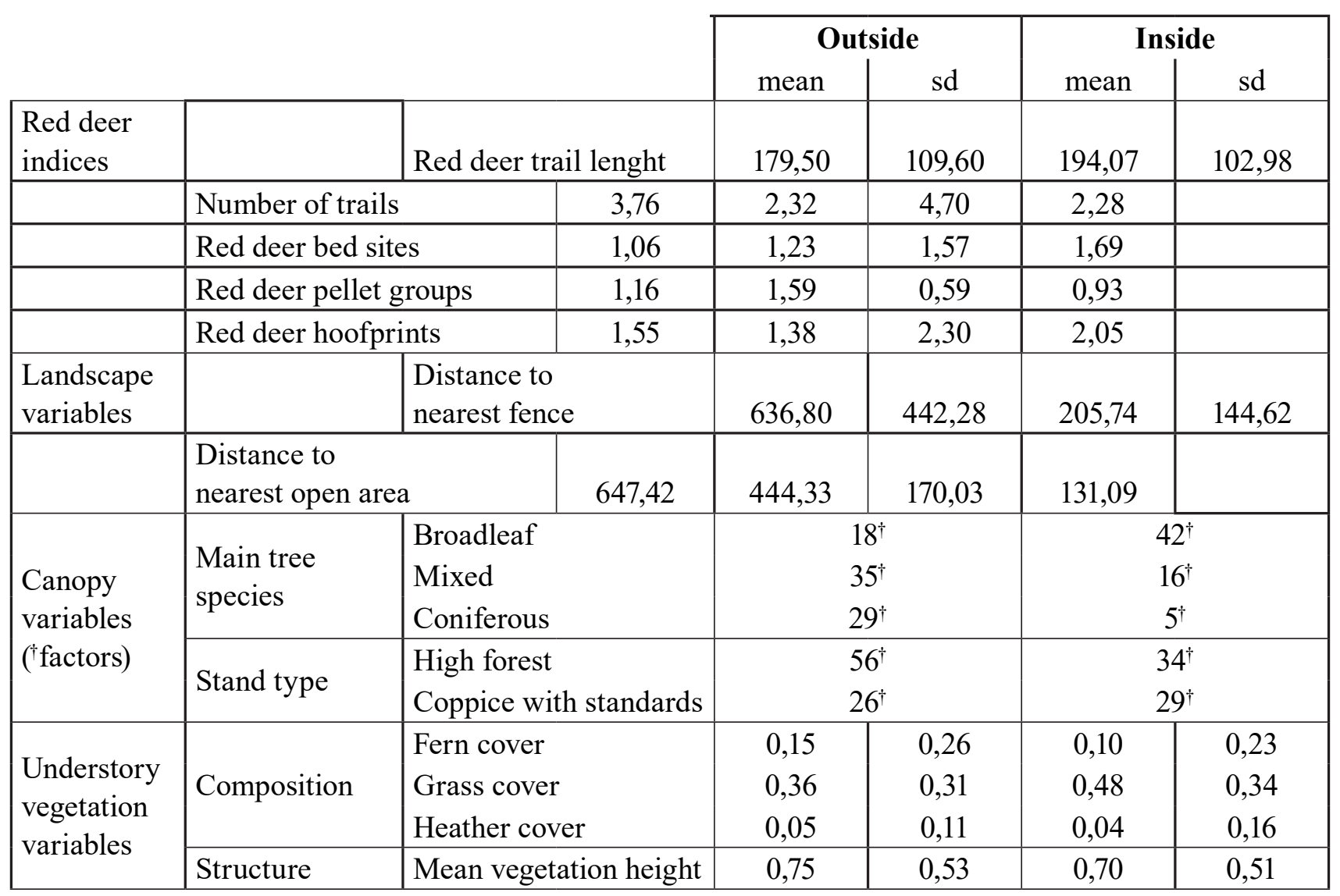


Table 3: Summary of the best models for each red deer presence indicator variable. In bold: overall best model from either the "vegetation composition" or "vegetation structure" model families; in italics, the best model according to the family considered.

\begin{tabular}{|c|c|c|c|c|c|c|c|c|c|c|c|c|c|c|c|c|c|c|c|c|c|c|c|c|c|c|c|}
\hline & & & egeta & ation & Str & uctur & e $M$ & odel & & & & & & & & & etat & tion C & iom & osit & tion $\mathrm{N}$ & Mod & & & & & \\
\hline$\frac{u}{a}$ & 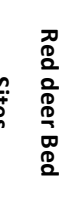 & & $\begin{array}{l}\frac{0}{0} \\
\frac{0}{0} \\
\frac{0}{n}\end{array}$ & $\begin{array}{l}\text { ग0 } \\
0 \\
0 \\
0 \\
0 \\
0 \\
0 \\
0 \\
0\end{array}$ & & & 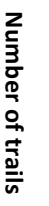 & & & 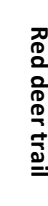 & & & & & $\begin{array}{l}\text { ग0 } \\
0 \\
0 \\
0 \\
0 \\
0 \\
0 \\
0 \\
0 \\
0\end{array}$ & & & $\begin{array}{l}\text { Do } \\
0 \\
0 \\
0 \\
0 \\
0 \\
0 \\
0 \\
0 \\
\\
\end{array}$ & & & 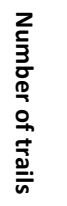 & & & 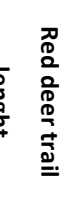 & & & \\
\hline$\stackrel{\mathbb{T}}{\leftrightarrows}$ & $\underline{\underline{\underline{z}}}$ & 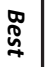 & $\underline{\underline{m}}$ & 莹 & 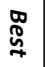 & $\stackrel{\pi}{\Xi}$ & 总 & 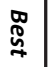 & $\stackrel{\mathfrak{I}}{\underline{I}}$ & 竞 & 总 & & & $\stackrel{\mathbb{m}}{\underline{\underline{n}}}$ & $\underline{\underline{\underline{z}}}$ & 恋 & $\stackrel{\underline{\underline{I}}}{\underline{\underline{n}}}$ & $\underline{\underline{\underline{z}}}$ & 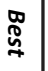 & $\stackrel{\mathbb{T}}{\leftrightarrows}$ & 竞 & 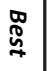 & $\stackrel{\mathbb{T}}{\underline{\Xi}}$ & 莹 & 思 & & \\
\hline $\begin{array}{l}\dot{D} \\
\dot{a} \\
\dot{b}\end{array}$ & $\stackrel{\circ}{\stackrel{\sim}{\tilde{U}}}$ & $\begin{array}{l}\dot{0} \\
\text { :े }\end{array}$ & 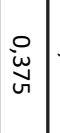 & $\begin{array}{l}\dot{d} \\
\dot{\omega} \\
0\end{array}$ & $\begin{array}{l}0 \\
\text { in } \\
\infty \\
\infty\end{array}$ & 它 & $\begin{array}{l}\stackrel{\vec{\omega}}{\omega} \\
\stackrel{0}{0}\end{array}$ & 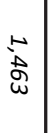 & $\mid \begin{array}{c}\tilde{N} \\
\infty \\
\infty \\
o \\
0 \\
\end{array}$ & 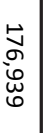 & 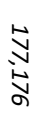 & 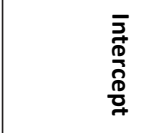 & & $\mid \begin{array}{c}\dot{b} \\
\dot{\omega} \\
\stackrel{+}{\mid}\end{array}$ & 怘 & 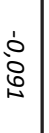 & $\begin{array}{l}0 \\
0 \\
0 \\
0\end{array}$ & 䓪 & : & $\begin{array}{c}\stackrel{+}{o} \\
\stackrel{w}{w}\end{array}$ & 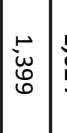 & 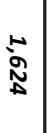 & 苓 & $\mid$\begin{tabular}{|l}
$\vec{\alpha}$ \\
0 \\
$\omega$ \\
$\omega$ \\
0
\end{tabular} & 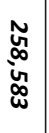 & 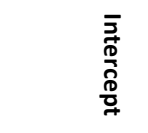 & \\
\hline $\begin{array}{l}\stackrel{\bigcirc}{0} \\
\substack{0 \\
\infty}\end{array}$ & ' & :̊. & $\begin{array}{l}1 \\
0 \\
0 \\
\infty \\
\infty\end{array}$ & ' & $\begin{array}{c}\dot{\vec{\omega}} \\
\dot{\omega} \\
\infty\end{array}$ & 总 & ' & 2 & 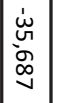 & & 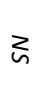 & $\frac{\overline{\bar{v}}}{\frac{\underline{a}}{0}}$ & & 宔 & & $\begin{array}{l}0 \\
\stackrel{\vec{\omega}}{\omega} \\
0\end{array}$ & ì & & $\begin{array}{l}\dot{0} \\
\dot{0} \\
\vdots\end{array}$ & $\begin{array}{l}0 \\
\stackrel{0}{o} \\
\stackrel{0}{\omega}\end{array}$ & . & $z_{n}$ & 点 & . & $z_{n}$ & $\frac{\overline{\bar{v}}}{\frac{\bar{a}}{0}}$ & \\
\hline & & & & & & & & & & & & & 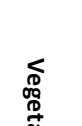 & 恙 & & $z_{n}$ & 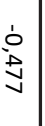 & & $z_{n}$ & 芯 & . & z & 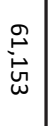 & ' & $z_{n}$ & $\stackrel{\substack{\mathbf{I} \\
\stackrel{D}{\varpi}}}{\stackrel{\varpi}{*}}$ & 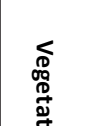 \\
\hline in & ' & $\begin{array}{l}0 \\
\text { ì } \\
\text { - }\end{array}$ & 足 & ' & 2 & : & ' & $\begin{array}{l}0 \\
\stackrel{\sim}{\infty} \\
\infty\end{array}$ & 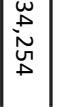 & & 怘 & 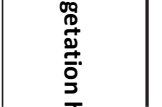 & $\begin{array}{l}\overline{0} \\
\overline{0} \\
\bar{n} \\
\stackrel{n}{n} \\
\bar{n}\end{array}$ & $\dot{\omega}_{\stackrel{\omega}{\omega}}$ & & $z_{n}$ & $\begin{array}{l}\dot{1} \\
\infty \\
\infty \\
\infty\end{array}$ & & $z_{n}$ & 家 & . & $\stackrel{\circ}{\circ}$ & 离 & . & z & ؛̊ & $\begin{array}{l}\overline{0} \\
0 \\
0 \\
3 \\
3 \\
0\end{array}$ \\
\hline & & & & & 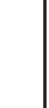 & & & & & & & $\frac{\underline{0}}{\frac{0}{90}}$ & $\frac{\tilde{T}}{\overline{0}}$ & 睤 & & $z_{n}$ & 总 & & ڤั. & : & ' & 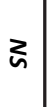 & $\stackrel{\vec{t}}{\stackrel{s}{\rho}}$ & ' & 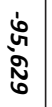 & ?̊̊ & $\frac{\underline{0}}{\bar{z}}$ \\
\hline $\begin{array}{l}\circ \\
\vdots \\
\circ\end{array}$ & ' & $\stackrel{8}{\circ}$ & : & ' & 2 & 용 & ' & in & $\begin{array}{l}0 \\
0 \\
0 \\
\bullet\end{array}$ & ' & is & 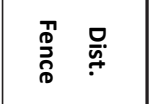 & $\frac{\bar{y}}{\bar{z}}$ & 遂 & & $\begin{array}{l}\circ \\
\vdots \\
\vdots\end{array}$ & ஜे & & $z_{n}$ & $\stackrel{\circ}{\circ}$ & ' & $z_{n}$ & $\begin{array}{l}\dot{0} \\
\vdots \\
0\end{array}$ & ' & $z_{n}$ & 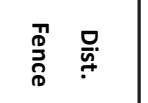 & $\frac{5}{30}$ \\
\hline : & ' & : & i & ' & ¿ें & 官 & ' & $\begin{array}{l}\dot{0} \\
\grave{2}\end{array}$ & $\mid \begin{array}{l}0 \\
\dot{0} \\
\dot{0} \\
\omega\end{array}$ & & $\begin{array}{l}\dot{0} \\
\stackrel{\infty}{\infty} \\
\omega\end{array}$ & 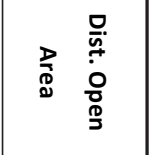 & 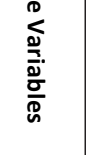 & 家 & & $\begin{array}{l}1 \\
\vdots \\
\vdots \\
0\end{array}$ & : & & ¿े & : & ' & $\begin{array}{l}1 \\
\vdots \\
\vdots\end{array}$ & 苞 & ' & : & 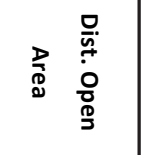 & 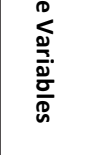 \\
\hline & & & & & & & & & & & & 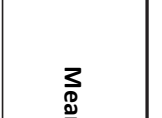 & 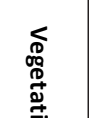 & 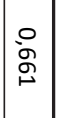 & & in & जे & & $z_{n}$ & 宫 & ' & $z_{n}$ & 离 & ' & $z_{n}$ & 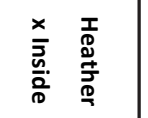 & 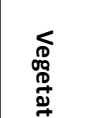 \\
\hline ڤें & & $\begin{array}{l}\dot{0} \\
\infty \\
\infty \\
\infty \\
\infty\end{array}$ & 童 & & 2 & 遂 & ' & $z_{n}^{2}$ & 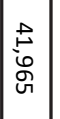 & & $z_{n}$ & 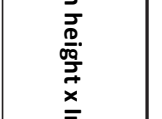 & 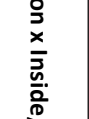 & $\underset{\substack{\hat{N} \\
\infty}}{\infty}$ & & in & 品 & & $z_{n}$ & 宓 & ' & z & 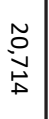 & . & $z_{n}$ & 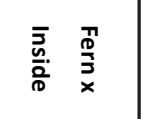 & $\begin{array}{l}\frac{9}{3} \\
\frac{x}{5} \\
\frac{\vec{n}}{\frac{0}{0}} \\
\frac{0}{0}\end{array}$ \\
\hline & & & & & & & & & & & & $\frac{u}{d}$ & 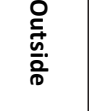 & 总 & & in & \begin{tabular}{l}
$\dot{0}$ \\
$\infty$ \\
$\infty$ \\
\multirow{\infty}{*}{}
\end{tabular} & & z & $\stackrel{\circ}{\vec{\Delta}}$ & . & $z_{1}$ & $\stackrel{\dot{⿱}}{\stackrel{N}{N}}$ & ' & z & 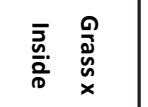 & 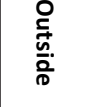 \\
\hline : & ' & $z_{n}$ & 兽 & ' & $z_{n}$ & 웅 & ' & $z_{n}$ & 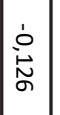 & ' & $z_{n}$ & 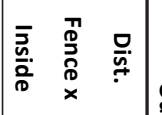 & 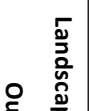 & ì & & $z_{n}$ & : & & 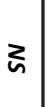 & $\stackrel{\circ}{\circ}$ & ' & 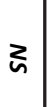 & 定 & ' & $z_{4}$ & 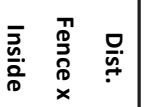 & 음 \\
\hline : & ' & : & 容 & ' & z & : & ' & $z_{n}$ & $\begin{array}{l}\dot{0} \\
\dot{0} \\
\dot{b}\end{array}$ & ' & in & 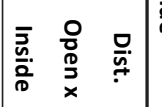 & 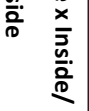 & 品 & & : & 定 & & z & $\stackrel{\circ}{\circ}$ & ' & 2 & $\begin{array}{l}\dot{0} \\
\vdots \\
\vdots \\
\vdots\end{array}$ & ' & is & 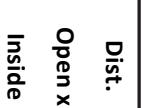 & $\mid$ \\
\hline 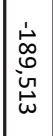 & $\mid$ & 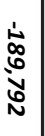 & 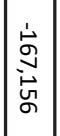 & 定 & 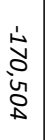 & $\mid \begin{array}{c}\dot{\alpha} \\
\vdots \\
+ \\
\infty \\
\infty \\
\infty\end{array}$ & 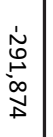 & 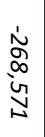 & 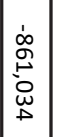 & 怘 & 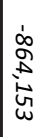 & 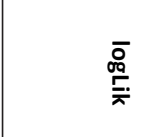 & & 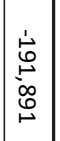 & 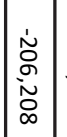 & $\begin{array}{l}\dot{b} \\
\vdots \\
\vdots \\
\vdots\end{array}$ & 岕 & $\mid$ & 灾 & 芯 & 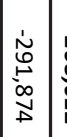 & 芯 & $\begin{array}{l}\dot{1} \\
0 \\
\infty \\
\infty \\
0 \\
o \\
o\end{array}$ & 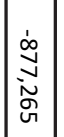 & 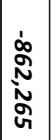 & 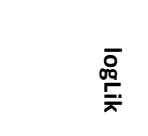 & \\
\hline 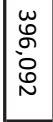 & 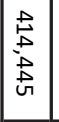 & 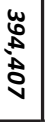 & $\mid$\begin{tabular}{|c|}
$\underset{\omega}{\omega}$ \\
$\stackrel{\omega}{\omega}$ \\
$\circlearrowleft$ \\
\end{tabular} & 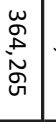 & 岕 & 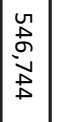 & 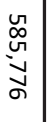 & 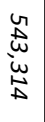 & 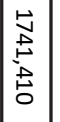 & 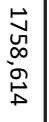 & 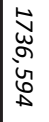 & $\frac{D}{n}$ & & $\mid \begin{array}{l}\vec{B} \\
0 \\
\dot{b} \\
\dot{+} \\
\end{array}$ & 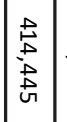 & 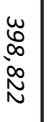 & 位 & 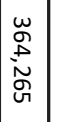 & . & $\begin{array}{l}\stackrel{U}{N} \\
\stackrel{N}{N}\end{array}$ & 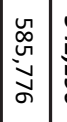 & 岕 & 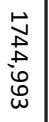 & 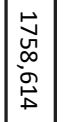 & 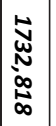 & $\stackrel{2}{n}$ & \\
\hline & I & & & I & & & $\begin{array}{l}\frac{I}{2} \\
\text { 焉 } \\
\text { I } \\
\omega\end{array}$ & & & $\begin{array}{l}\frac{I}{د} \\
\text { I } \\
\text { I } \\
\text { W }\end{array}$ & & 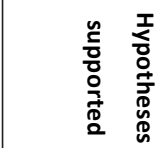 & & & I & & & $\stackrel{I}{\omega}$ & & & 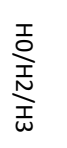 & & & 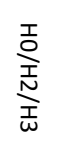 & & 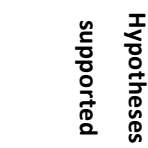 & \\
\hline
\end{tabular}




\section{REFERENCES}

Anderson, D., Forester, J., \& Turner, M. 2008. "When to Slow Down: Elk Residency Rates on a Heterogeneous Landscape." Journal of Mammalogy, 89(1), 105-114. doi: 10.1644/07-MAMM-A-035.1

Baltzinger, C. 2003. Sélection des sitesde repos par le cerf (Cervus Elaphus L.) et le chevreuil (Capreolus Capreolus L.) vivant en sympatrie en forêt tempérée de moyenne montagnemontagne, PhD Thesis. Ecole Nationale du Génie Rural, des Eaux et Forêts, Paris.

Baltzinger, M., Mårell, A., Archaux, F., Pérot, T., Leterme, F., \& Deconchat, M. 2016. "Overabundant ungulates in French Sologne? Increasing red deer and wild boar pressure may not threaten woodland birds in mature forest stands." Basic and Applied Ecology, 17(6), 552-563. doi: 10.1016/j.baae.2016.04.005

Baltzinger, M., Mouche, J., Blondet, M., \& Hautdidier, B. 2016. "Political ecology de I' forestier privé en Sologne : quels sont les enjeux socioenvironnementaux au cœur du conflit ?" Natures Sciences Sociétés, 24, 97-108.

Barton, K. 2013. Package 'MuMIn'. Retrieved from http://cran.r-project.org/web/ packages/MuMIn/MuMIn.pdf

BIPE. 2015. "France - Impact économique, social, culturel et environnemental de la filière chasse." Retrieved from http://chasseurdefrance.com/wp-content/uploads/2015/07/fnc-etude_socioeco_numerique_nationale-V2-juillet-2016.pdf

Boulanger, V. 2010. Pression d'herbivorie et dynamique des communautés végétales : influence à court et moyen termes des populations de cervidés sur la diversité des communautés végétales en forêt (PhD Thesis). Université Henri Poincaré, Nancy. Retrieved from http://www.theses.fr/14769695X

Bressette, J. W., Beck, H., \& Beauchamp, V. B. 2012. "Beyond the browse line: complex cascade effects mediated by white-tailed deer." Oikos, 1749-1760. doi: 10.1111/j.1600-0706.2011.20305.x

Brighenti, A. M. 2010. "On Territorology: Towards a General Science of Territory." Theory, Culture \& Society, 27(1), 52-72. doi: 10.1177/0263276409350357

Bromberger, C., \& Lenclud, G. 1982. "La chasse et la cueillette aujourd'hui. Un champ de recherche anthropologique ?" Études rurales, 87(1), 7-35. doi: 10.3406/rural.1982.2869

Burbaite, L., \& Csányi, S. 2009. "Roe deer population and harvest changes in Europe." Estonian Journal of Ecology, 58, 169-180. doi: 10.3176/eco.2009.3.02 
Burbaite, L., \& Csányi, S. 2010. "Red deer population and harvest changes in Europe." Acta Zoologica Lituanica, 20, 179-188. doi: 10.2478/v10043-010-0038-z

Burnham, K. P., \& Anderson, D. R. 1992. "Data-Based Selection of an Appropriate Biological Model: The Key to Modern Data Analysis." In D. R. McCullough \& R. H. Barrett (Eds.), Wildlife 2001: Populations. Springer Netherlands. 16-30. Retrieved from http://link.springer.com/chapter/10.1007/978-94-011-2868-1_3

Chamboredon, J.-C. 1982. "La diffusion de la chasse et la transformation des usages sociaux de l'espace rural." Études rurales, 87(1), 233-260. doi: 10.3406/rural.1982.2887

Chardon, E. 1993. Les conflits d'usages sur un territoire -L'exemple de St Viatre (Sologne), PhD Thesis. Université de Paris X, Nanterre.

Chollet, S. 2012. De la mise en évidence à la gestion de l'effet de cerf : Leçons pratiques et théoriques fournies par l'introduction du cerf à queue-noire sur Haïda Gwaii (PhD Thesis). Montpellier 2. Retrieved from http://www.theses.fr/2012MON20219

Clutton-Brock, J. 2002. "The unnatural world: behavioural aspects of humans and animals in the process of domestication." In Animals and Human Society: Changing Perspectives. Routledge. 23-35.

Clutton-Brock, T. H., \& Guinness, F. E. 1982. Red Deer: Behavior and Ecology of Two Sexes. University of Chicago Press.

Collins, W. B., \& Urness, P. J. 1981. "Habitat Preferences of Mule Deer as Rated by Pellet-Group Distributions." The Journal of Wildlife Management, 45(4), 969. doi: $10.2307 / 3808105$

Devilleger, C., Roulet, J., David, Y., Serre, D., Lesage, C., \& Reverchon, S. 2010. "Fragmentation du territoire par les clôtures : une dynamique préoccupante dans le Loiret - Etude d'impact sur le Cerf elaphe." Faune Sauvage, (289), 39-45.

ESRI. (n.d.). ArcGis Desktop: Release 9.3.1. Redlands, CA: Environmental Systems Research Institute.

FACE. 2010. Census of the number of hunters in Europe - September 2010. Retrieved from http://www.face.eu/sites/default/files/attachments/data_hunters-region_ sept_2010.pdf

FACE. 2016. "The Economic Value of Hunting in the EU." Retrieved from http://www. face.eu/about-us/resources/events/the-economic-value-of-hunting-in-the-euconference

Fahrig, L. 2003. "Effects of Habitat Fragmentation on Biodiversity." Annual Review of Ecology, Evolution, and Systematics, 34, 487-515.

Field, D., Voss, P., Kuczenski, T., Hammer, R., \& Radeloff, V. 2003. "Reaffirming Social Landscape Analysis in Landscape Ecology: A Conceptual Framework." Society \& Natural Resources, 16(4), 349-361. doi: 10.1080/08941920390178900 
Flyvbjerg, B. 2006. "Five Misunderstandings About Case-Study Research." Qualitative Inquiry, 12(2), 219-245. doi: 10.1177/1077800405284363

Froissart, Y. 2011. "Faire face aux engrillagements en Grande Sologne." Trans-Formation Consultats.

Fryxell, J. M., Hazell, M., Börger, L., Dalziel, B. D., Haydon, D. T., Morales, J. M., Mclntosh, T., Rosatte, R. C. 2008. "Multiple movement modes by large herbivores at multiple spatiotemporal scales." Proceedings of the National Academy of Sciences, 105(49), 19114-19119. doi: 10.1073/pnas.0801737105

García-Nieto, A. P., García-Llorente, M., Iniesta-Arandia, I., \& Martín-López, B. 2013. "Mapping forest ecosystem services: From providing units to beneficiaries." Ecosystem Services, 4, 126-138. doi: 10.1016/j.ecoser.2013.03.003

Gaudio, N. 2010. Interactions pour la lumière entre les arbres adultes, les jeunes arbres et la végétation du sous-bois au sein d'un écosystème forestier : application à la régénération du pin sylvestre en peuplement mélangé chêne sessile - pin sylvestre. Orléans. Retrieved from http://www.theses.fr/20100RLE2033

Gebert, C., \& Verheyden-Tixier, H. 2008. "Variations of diet composition of Red Deer (Cervus elaphus L.) in Europe." Mammal Review, 31(3-4), 189-201. doi: 10.1111/j.1365-2907.2001.00090.x

Geisser, H., Reyer, H.-U., \& Krausman. 2004. "Efficacy of hunting, feeding, and fencing to reduce crop damage by wild boars." Journal of Wildlife Management, 68(4), 939946. doi: 10.2193/0022-541X(2004)068[0939:EOHFAF]2.0.CO;2

Gillardot, P. 1981. La Grande Sologne, PhD Thesis. Université de Paris I - Pantheon Sorbonne, Paris.

Hamann, J., Klein, F., \& Saint Andrieux, C. 1997. "Domaine vital diurne et déplacements de biches (Cervus elaphus) sur le secteur de la Petite Pierre (Bas-Rhin)." Gibier Faune Sauvage, 14, 1-17.

Heley, J., \& Jones, L. 2012. "Relational rurals: Some thoughts on relating things and theory in rural studies." Journal of Rural Studies, 28(3), 208-217. doi: 10.1016/j.jrurstud.2012.01.011

Hell, B. 1998. Le sang noir : Chasse et mythe du sauvage en Europe. Paris: Flammarion.

Hothorn, T., \& Müller, J. 2010. "Large-scale reduction of ungulate browsing by managed sport hunting." Forest Ecology and Management, 260(9), 1416-1423. doi: 10.1016/j. foreco.2010.07.019

Ingold, T. 1987. The Appropriation of Nature: Essays on Human Ecology and Social Relations. University of lowa Press.

Jacquet, H. 2008. "Halte aux clôtures !" Journal de Gien. 
Jayakody, S., Sibbald, A. M., Gordon, I. J., \& Lambin, X. 2008. "Red deer Cervus elephus vigilance behaviour differs with habitat and type of human disturbance." Wildlife Biology, 14(1), 81-91. doi: 10.2981/0909-6396(2008)14[81:RDCEVB]2.0.CO;2

Lee, R. B., \& DeVore, I. 1966. Man the Hunter. Aldine De Gruyter.

Legall, V. 2012. "Trop de grillage en Sologne ? Des réponses à l'automne." La République Du Centre. Retrieved from http://www.lanouvellerepublique.fr/Loir-et-Cher/ Actualite/Environnement/n/Contenus/Articles/2012/03/13/Trop-de-grillage-enSologne-Des-reponses-a-I-automne

Levers, C., Müller, D., Erb, K., Haberl, H., Jepsen, M. R., Metzger, M. J., ... Kuemmerle, T. 2015. "Archetypical patterns and trajectories of land systems in Europe." Regional Environmental Change, 1-18. doi: 10.1007/s10113-015-0907-x

Lévi-Strauss, C. 1962. La pensée sauvage (Revised). Pocket.

Martin, J. L., \& Baltzinger, C. 2002. "Interaction among deer browsing, hunting, and tree regeneration." Canadian Journal of Forest Research, 32(7), 1254-1264.

Massei, G., Kindberg, J., Licoppe, A., Gačić, D., Šprem, N., Kamler, J., ... Náhlik, A. 2015. "Wild boar populations up, numbers of hunters down? A review of trends and implications for Europe." Pest Management Science, 71(4), 492-500. doi: 10.1002/ps.3965

Masson, M. 2015. Influence of habitat fragmentation and historical context on the genetic structure of red deer (Cervus elaphus), Master of science thesis. Université Paul Sabatier, Toulouse.

Mather, A. S., Fairbairn, J., \& Needle, C. L. 1999. "The course and drivers of the forest transition: The case of France." Journal of Rural Studies, 15(1), 65-90. doi: 10.1016/ S0743-0167(98)00023-0

Matthews, J. D. 1991. Silvicultural Systems. Clarendon Press.

Mendel, G. 1977. La Chasse structurale : Une interprétation de devenir humain. Payot.

Mouche, J. 2013. Comment l'engrillagement en Sologne questionne-t'il les valeurs associées à la forêt Recherche exploratoire sur l'intéraction homme-nature dans le contexte de la propriété privée, Master of Science thesis. MNHN, Paris.

Mounet, C. 2012. "Conflits et reconfigurations socio-spatiales autour du sanglier. Des postures générales aux arrangements locaux." Économie rurale, 327-328(1), 79-95.

Mysterud, A. 1998. "The relative roles of body size and feeding type on activity time of temperate ruminants." Oecologia, 113(3), 442-446. doi: 10.1007/s004420050396

Mysterud, A., \& Ims, R. A. 1998. "Functional Responses in Habitat Use: Availability Influences Relative Use in Trade-Off Situations." Ecology, 79(4), 1435-1441. doi: 10.1890/0012-9658(1998)079[1435:FRIHUA]2.0.CO;2 
Navarro, L. M., \& Pereira, H. M. 2015. "Rewilding Abandoned Landscapes in Europe." In Rewilding European Landscapes. Springer, Cham. 3-23. doi: 10.1007/978-3-31912039-3_1

ONCFS. 2011. "Attributions et Réalisations des plans de Chasse Nationaux par Département." Réseau Ongulés Sauvage. France. ONCFS.

Owen-Smith, N., Fryxell, J. M., \& Merrill, E. H. 2010. "Foraging theory upscaled: the behavioural ecology of herbivore movement." Philosophical Transactions of the Royal Society B: Biological Sciences, 365(1550), 2267-2278. doi: 10.1098/rstb.2010.0095

Patthey, P. 2003. Habitat and corridor selection of an expanding red deer (cervus elaphus) population, Phd Thesis. Faculté des Ciences de l'Université de Lausanne.

Pellerin, M., Saïd, S., Richard, E., Hamann, J.-L., Dubois-Coli, C., \& Hum, P. 2010. "Impact of deer on temperate forest vegetation and woody debris as protection of forest regeneration against browsing." Forest Ecology and Management, 260(4), 429-437. doi: 10.1016/j.foreco.2010.04.031

Pelosse, V., \& Vourc'h, A. 1982. "Chasse au sanglier en Cévennes." Études rurales, (8788), 295-308.

Peluso, N., \& Lund, C. 2011. "New frontiers of land control: Introduction." The Journal of Peasant Studies, 38(4), 667-681.

Philo, C., \& Wilbert, C. 2000. Animal Spaces, Beastly Places: New Geographies of Human-Animal Relations. London and New York: Routledge.

Poinsot, Y. 2017. "Geographic combinations and social arrangements in the rural space." L'Espace Géographique, Volume 46(1), 4-18.

Poinsot, Y., \& Saldaqui, F. 2012. "La maîtrise des populations de grands ongulés dans les espaces naturels protégés : comment gérer la spatialité animale par des territoires humains ?" Cybergeo : European Journal of Geography. doi: 10.4000/cybergeo.25226

Pollard, J. H., Palka, D., \& Buckland, S. T. 2002. "Adaptive Line Transect Sampling." Biometrics, 58(4), 862-870. doi: 10.1111/j.0006-341X.2002.00862.x

R Core Team. 2011. "R: A language and environment for statistical computing." Vienna, Austria: R Foundation for Statistical Computing. Retrieved from http://www.Rproject.org/

Ribot, J. C., \& Peluso, N. L. 2003. "A Theory of Access*". Rural Sociology, 68(2), 153181. doi: 10.1111/j.1549-0831.2003.tb00133.x

Rooney, T. P., \& Waller, D. M. 2003. "Direct and indirect effects of white-tailed deer in forest ecosystems." Forest Ecology and Management, 181(1-2), 165-176. doi: $10.1016 /$ S0378-1127(03)00130-0 
Saïd, S., Tolon, V., Brandt, S., \& Baubet, E. 2011. "Sex effect on habitat selection in response to hunting disturbance: the study of wild boar." European Journal of Wildlife Research, 58(1), 107-115. doi: 10.1007/s10344-011-0548-4

Schulp, C. J. E., Thuiller, W., \& Verburg, P. H. 2014. "Wild food in Europe: A synthesis of knowledge and data of terrestrial wild food as an ecosystem service." Ecological Economics, 105, 292-305. doi: 10.1016/j.ecolecon.2014.06.018

Somers, M. J., \& Hayward, M. 2011. "Fencing for Conservation: Restriction of Evolutionary Potential or a Riposte to Threatening Processes?" Springer Science \& Business Media.

Storms, D. 2006. Utilisation, sélection et partage des ressources par le Cerf et le Chevreuil, Phd Thesis. AgroParisTech.

van Vliet, J., de Groot, H. L. F., Rietveld, P., \& Verburg, P. H. 2015. "Manifestations and underlying drivers of agricultural land use change in Europe." Landscape and Urban Planning, 133, 24-36. doi: 10.1016/j.landurbplan.2014.09.001

Wallis De Vries, M. F. 1995. "Large Herbivores and the Design of Large-Scale Nature Reserves in Western Europe." Conservation Biology, 9(1), 25-33.

Webb, S., Gee, K., \& Wang, G. 2010. "Survival and fidelity of an enclosed white-tailed deer population using capture-recapture-reporting data." Population Ecology, 52(1), 81-88. doi: 10.1007/s10144-009-0178-9

Young, A., \& Betham-Edwards, M. 2015. "Arthur Young's Travels in France During the Years 1787, 1788, 1789." Bibliolife DBA of Bibilio Bazaar II LLC. 


\section{ANNEX 1: QUOTATIONS IN FRENCH}

(1) Bah moi je connais guère quand même de propriétaires qui mettent du grillage pour empêcher les animaux de rentrer! Surtout pour les empêcher de sortir ! [...] Et puis en plus ça fait ça empêche les animaux de sortir et ça dissuade euh même si il fait un tant soit peu un mètre euh les gens ne vont pas rentrer!

(2) Alors après y'a des des flux hein [...]. Effectivement des coulées si on regarde des coulées. [...] Ah mais y'en a énormément des coulées ! [...] Des coulées y'en aura partout hein! [...] ça rentre et ça sort comme ça on va dire euh tout du long hein.

(3) Bah un piège pourquoi ? Parce que quand vous avez [...] Je veux dire si vous avez un endroit où vous devez privilégier pour faire des prélèvements... Si moi je suis désolé c'est un piège quelque part! [...] moi on me demande de chasser ces animaux-là euh je sais où je vais me mettre je veux dire pour les prélever!

(4) Bon, donc généralement est-ce que vous dormez dans votre salle à manger ? Non vous dormez dans votre chambre. Bon, les animaux ils viennent manger et le soir ils la nuit ils viennent bouffer et le matin ils rentrent dormir chez moi.

(5) Oui mais les les dégâts vous les avez quand même parce que les animaux viennent la nuit. [...] Donc c'est un constat euh je vous dirais ben oui effectivement les animaux sont plus chez nous ben oui ! [...] mais ils sont quand même sur le territoire sur le sur le grand territoire. Bon. Donc ils reviennent manger [...] Ils font l'aller-retour euh c'est la transhumance nocturne euh c'est les grandes distances hein! [...]

(6) L'endroit où on tue le plus de cerfs de toute la région c'est ici! [...]. Bon, très rapidement: y'aura plus un animal nulle part et ils seront tous chez nous. [...]. Donc notre pari c'est que la population globale baisse et comme la population globale ayant baissé, nous on aura toujours de quoi chasser.

(7) Nous euh pour essayer de faire le plan de chasse à une époque se lever à 4 heures du matin pour essayer de mettre des rubalises pour essayer de les empêcher de rentrer dans ce parc! Et on euh moi je parle pas de deux animaux hein! C'était euh mettre des rubalises sur 1,5 km parce qu'on était obligés de les prendre au large hein!

(8) Deux aux cent ha c'est un non-sens; c'est un non-sens; Moi à mon avis une population équilibrée c'est entre 3 et 4 cervidés aux cent ha voilà. Ben c'est ça qu'il faut. Voilà à mon avis c'est le minimum; Cinq c'est trop faut pas passer cinq. Bon cinq c'est bon on est déjà il faut déjà prendre des mesures mais trois quatre animaux c'est l'idéal.

(9) Si on était à je dirais 2 animaux aux cent ha euh ça nous dérangerait pas du tout hein [...] Y'a une note de service hein euh interne à l'office de 1994 euh notre milieu ils préconisent 1,5 à deux cerfs aux cent ha. 
We asked the stakeholders to draw red deer movements on a printed map with colored pens. Here, red deer movements are in green and red deer populations in red. In addition, forested areas are also shown in grey. Blue stars represent human disturbance for red deer: the higher the star, the greater the disturbance. The map was then digitalized and processed to enhance readability.

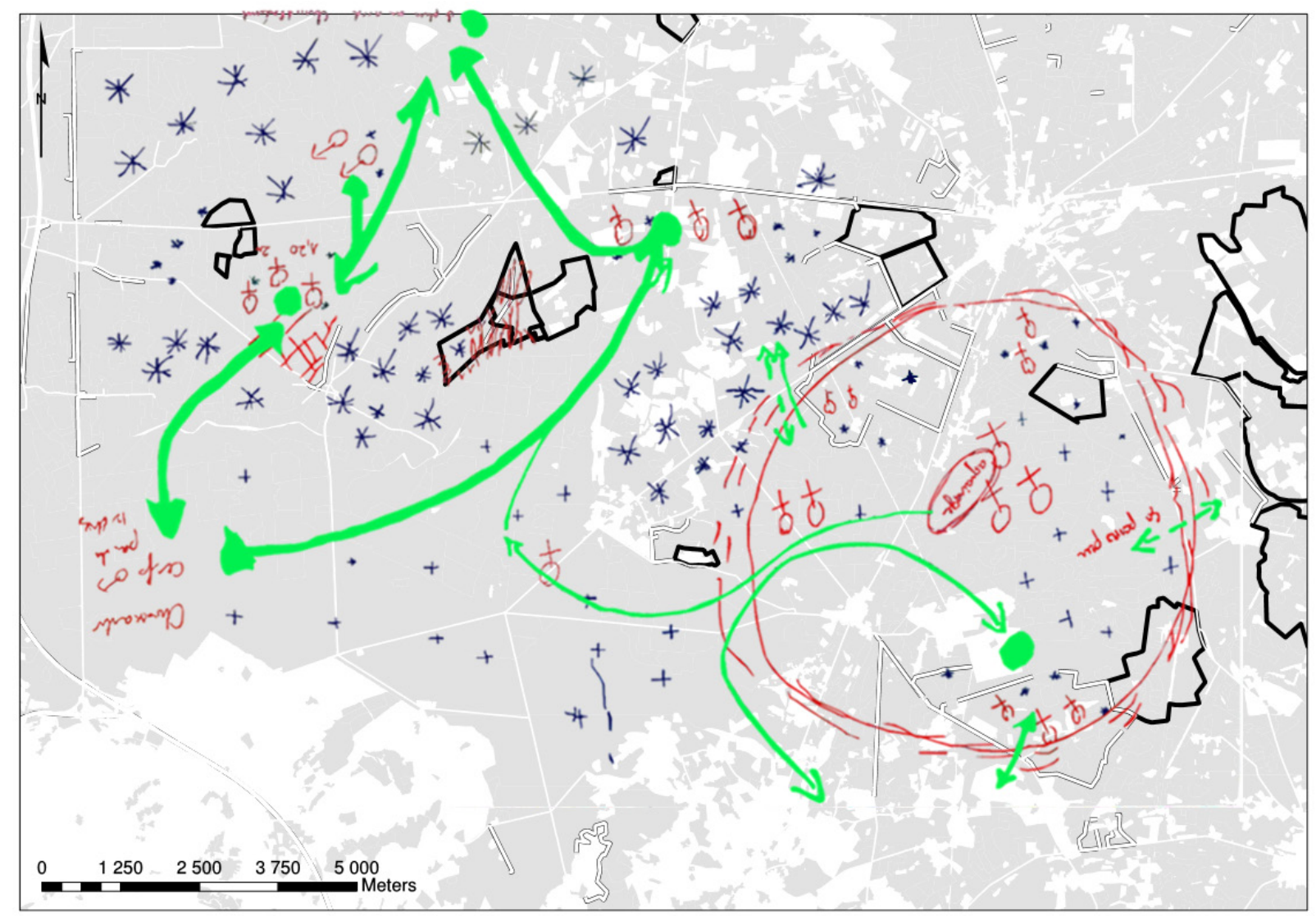




\section{ANNEX 3 : RED DEER MOVEMENTS AND RED DEER POPULATIONS AS DRAWN BY FORESTERS}

We asked the stakeholders to draw red deer movements on a printed map with colored pens. Here, red deer movements are in yellow and pink. ZQ indicates a sheltering area, yellow circles are rutting areas. Two separate red deer populations are indicated by the pink dotted line. In addition, forested areas are also shown in purple. The map was then digitalized and processed to enhance readability.

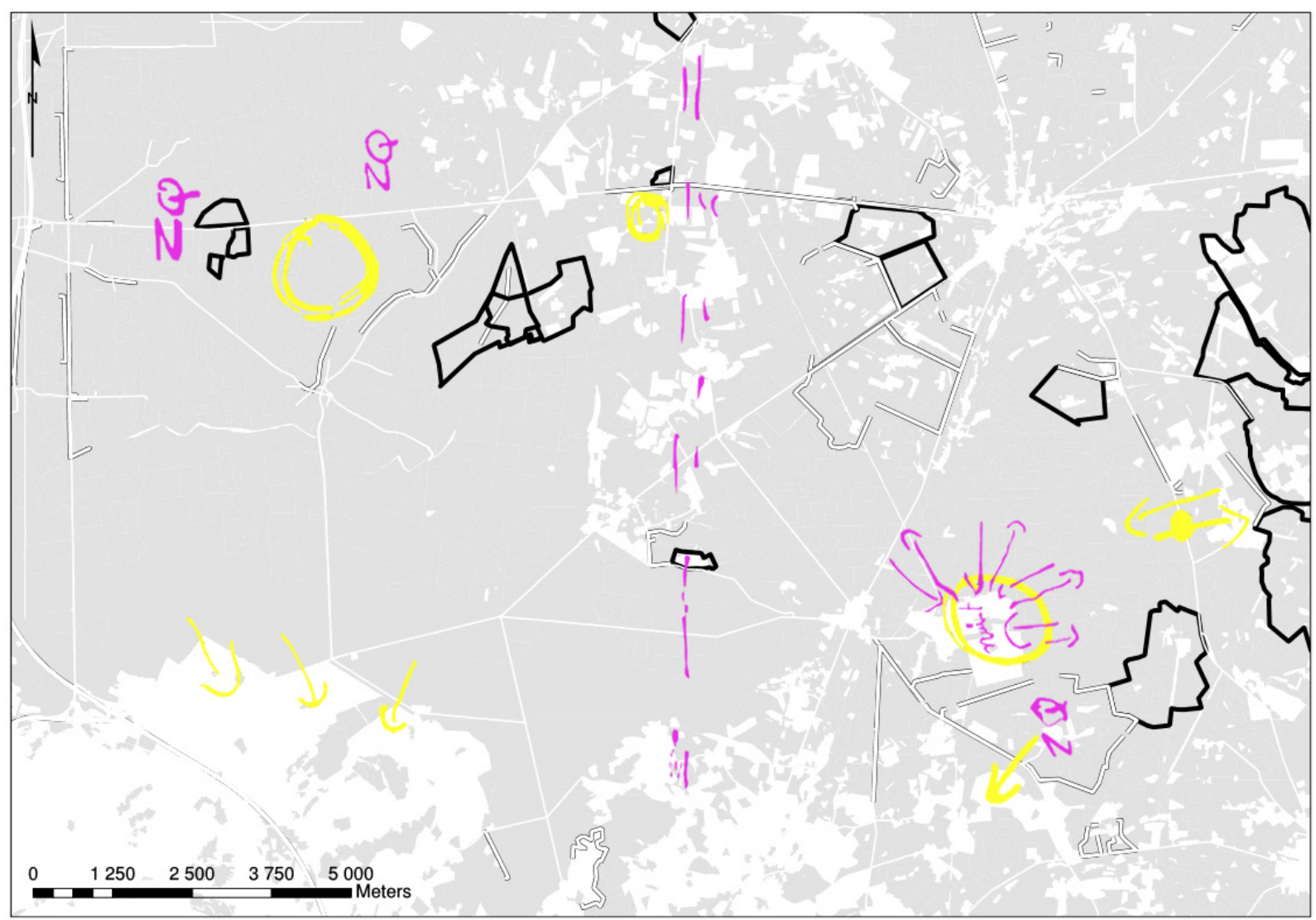

